\title{
Decrypting silicic magma/plug fragmentation at Azufral crater lake, Northern Andes: insights from fine to extremely fine ash morpho-chemistry
}

\author{
Natalia Pardo ${ }^{1}$ (D) - Jose D. Avellaneda ${ }^{1,2}$ - Juanita Rausch ${ }^{3}$. David Jaramillo-Vogel ${ }^{3}$ Mariana Gutiérrez $^{1}$. \\ Anneleen Foubert ${ }^{4}$
}

\begin{abstract}
Azufral (SW Colombia) is a dangerous silicic volcano hosting a crater lake, which serves as an excellent example of an incipient plug disruption through phreatomagmatism. We studied the youngest succession of dilute pyroclastic density currents (PDCs) onlapping the north-eastern crater rim. Scanning electron microscopy coupled with energy-dispersive X-ray spectroscopy was used to carry out an automated single-particle analysis of fine to extremely fine ash. We were able to obtain fast and accurate chemical analysis and imaging of 15,098 particles within the $250-63-\mu \mathrm{m}$ and the $63-32-\mu \mathrm{m}$ size ranges. The $2 \mathrm{D}$ form and roughness parameters were determined for 4895 juvenile glassy particles and validated by 3D micro-X ray computer tomography. There are two end members of high (group 1) and low (group 2) roughness juvenile glassy particles. Group 1 comprises high-roughness glass particles with solidity values as low as 0.34 in $2 \mathrm{D}$ and 0.33 in $3 \mathrm{D}$, and convexity values as low as 0.33 in $2 \mathrm{D}$ and 0.26 in $3 \mathrm{D}$. Group 2 comprises low-roughness glass particles with $2 \mathrm{D}$ solidity values $>0.79$ and $3 \mathrm{D}$ solidity values typically $>0.58$. In this group, $2 \mathrm{D}$ convexity values are $>0.68$ and $3 \mathrm{D}$ convexity values are $>0.71$. Both end members are mostly discriminated by the $2 \mathrm{D}$ Concavity Index ( 0.14 to 0.77 in group 1 vs. $0.05-0.35$ in group 2$)$. The remaining group 3 comprises particles of intermediate roughness values. In this study, we show how an incipient plug developed over a short repose time might be subjected to only a few cycles of vesicle nucleation, collapse and densification, retaining the characteristics of juvenile glass. Each glassy juvenile ash type, defined by a particular morphology, roughness and microtexture can be linked to a density "stratified" conduit model. In Azufral, the capping and conduit lining dense regions and the permeable zones of the incipient plug likely cracked. The newly formed cracks could allow hydraulic forcing caused by external water and induce phreatomagmatic interaction. This interaction favoured the fine fragmentation of the plug while enhancing ongoing magmatic processes. Finally, the variations of bulk componentry provided clues on dilute pyroclastic density current transport and physical fractionation processes by secondary fragmentation, elutriation and interaction with the crater rim.
\end{abstract}

Keywords Crater lake $\cdot$ Morpho-chemical $\cdot$ Pyroclastic density currents $\cdot 2 \mathrm{D}$ and 3D roughness

Natalia Pardo

n.pardo@uniandes.edu.co

Jose D. Avellaneda

jdavellanf@eafit.edu.co

Juanita Rausch

juanita.rausch@particle-vision.ch

David Jaramillo-Vogel

david.jaramillo@particle-vision.ch

Mariana Gutiérrez

m.gutierrezg@uniandes.edu.co
Anneleen Foubert

anneleen.foubert@unifr.ch

1 Departmento de Geociencias, Universidad de Los Andes, cra 1 \# $18^{\mathrm{a}}-12$, Bogota DC, Colombia

2 Departamento de Ciencias de la Tierra, Universidad EAFIT, Cra 49 \# 7 Sur-50, Medellin, Colombia

3 Particle Vision GmbH, c/o FriUp, Annexe 2, Passage du Cardinal 11, 1700 Fribourg, Switzerland

4 Department of Geosciences, University of Fribourg, Ch. Du Musée 6, Fribourg, Switzerland 


\section{Introduction}

Medium-sized (VEI 2-3) volcanic eruptions expected at composite silicic volcanoes hosting crater lakes comprise Vulcanian and Surtseyan styles. Vulcanian eruptions are short-lived explosions resulting from the rapid decompression of quasi-stationary, highly viscous magma separated from the atmosphere by a lava dome or clog plugging the volcanic conduit (Wright et al. 2007). Shallow conduit, densitystratified plugs form during repose periods between eruptions upon cycles of vesiculation, degassing and densification at the top of the magma column (Wright et al. 2007; Giachetti et al. 2010; Bain et al. 2019).

One of the most intriguing research questions relative to Vulcanian eruptions regards the primary fragmentation mechanisms (Dingwell 1998; Cashman and Sheu 2015) affecting the relatively impermeable conduit plug and the underlying magma (Albiridov and Dingwell 2000; Cashman and Blundy 2000; Melnik and Sparks 2002; Mueller et al. 2005). In particular, the origin of explosive ash through magmatic or phreatomagmatic fragmentation nature is highly debated (cf., Wright et al. 2007; Cioni et al. 2008). Magmatic fragmentation can be triggered by permeability variation and overpressurization (Sparks 1997; Mueller et al. 2005) or by fracture propagation through the relatively rigid plug, leading to rapid decompression (Lavallée et al. 2013). Any of these fragmentation mechanisms may occur with or without interaction with external water (Sparks 1997; Starostin et al. 2005).

The explosive physical interaction of a rising magma that enters in direct contact with external water across a surface interface has been commonly described as a molten-fuel coolant interaction (MFCI) process (Heiken and Wohletz 1985; Zimanowski et al. 1998, 2015). Surtseyan eruptions (Moore 1967; Kokelaar 1983; Kilgour et al. 2010; Rouwet and Morrissey 2015) are a subtype of phreatomagmatic explosions (Belousov and Belousova 2001; Houghton et al. 2015; Liu et al. 2017). These eruptions generally relate to a higher degree of fragmentation efficiency and smaller dispersal areas compared with Vulcanian eruptions (Belousov and Belousova 2001; Németh et al. 2006). However, most cases of known Surtseyan eruptions involve basaltic magma, and documentation of silicic examples at continental arc stratovolcanoes is underrepresented. Studying the role of magmatic and environmental factors driving explosive eruptions at plugged conduits through crater lakes is crucial to understanding the complexity of magma/water interaction in these settings (Mastin and Witter 2000; Liu et al. 2017).

In the Northern Andes, many of the highly touristic Holocene dacitic volcanoes hosting crater lakes, surrounded by towns or declared natural and cultural protected areas, are prone to generate explosive events. These systems show low seismicity and have incomplete or poorly exposed geological records, and some lack historical documentation. Hence, there are large uncertainties when prognosing eruptive scenarios needed to mitigate risk. This is the case of the poorly understood Azufral volcano, in SW Colombia $\left(1^{\circ} 05^{\prime} \mathrm{N}-77^{\circ} 43^{\prime} \mathrm{W}\right.$; Fig. 1), which is considered one of the most dangerous in the Northern Andes (Cepeda et al. 1987; Droux and Delaloye 1996; Calvache et al. 2003). Azufral contains a summit crater and future highly energetic magmatic to phreatomagmatic and hydrothermal explosions are likely. Proximal $(<10 \mathrm{~km})$ exposures of dilute pyroclastic density currents (PDCs) and ballistics $<3924 \pm 52$ years cal BP surrounding the crater lake, and onlapping the north-eastern crater rim (Castilla et al. 2018), provide a great opportunity to study the mechanisms driving conduit plug disruption (Starostin et al. 2005) and base surges (Moore 1967; Belousov and Belousova 2001) at polygenetic silicic volcanoes hosting crater lakes.

Componentry has been widely used as key criteria to distinguish magmatic from phreatomagmatic, and phreatic origins (Sheridan and Wohletz 1983; Barberi et al. 1989). For instance, a phreatic explosion is characterized by the small volume of the ejecta and the absence of juvenile material (e.g. Pardo et al. 2014; Montanaro et al. 2016; Kilgour et al. 2019). Instead, phreatomagmatic explosions generally produce higher non-juvenile/juvenile proportions and finergrained juveniles than magmatic counterparts (Sheridan and Wohletz 1983; Barberi et al. 1989).

The surface features of fine (2-3 $\phi)$, very fine $(3-4 \phi)$ and extremely fine $(>4 \phi)$ juvenile glassy ash particles, where $\phi=$ $\log _{2}$ (diameter in $\mathrm{mm}$ ) following Krumbein (1934), and White and Houghton (2006), are also known to provide hints on the primary fragmentation processes, since these size fractions host "active particles" in phreatomagmatic cases (Zimanowski et al. 1991; Dellino and La Volpe 1996b; Büttner et al. 1999, 2002; Zimanowski et al. 2015). The explosive interaction of magma with external water dominantly produces blocky-shaped, equant glass shards with quenching cracks or stepped features in these size fractions (Heiken and Wohletz 1985; Büttner et al. 2002; Zimanowski et al. 2015; Liu et al. 2017).

Moreover, the internal microtextures of fine and very fine ash particles represent an archive of the final rheological state of the rising magma up the conduit (Taddeucci et al. 2002, 2007). In combination with particle morphology, both aspects provide information on the role of volatiles in fragmentation, where the interaction of fractures with the crystal-bearing microtexture and variable-sized vesicles in an expanding magma typically produces complex surfaces at all scales (Heiken and Wohletz 1985; Dellino and La Volpe 1996a, b; Büttner et al. 1999, 2002; Rausch et al. 2015; Nurfiani and de Maisonneuve 2018). Many studies have been carried out over the past few decades focusing on advances in 2D and 3D imaging and morphometry of volcanic ash, demonstrating that ash shape and internal microtexture parameters are intrinsically interlinked, and provide diagnostic information on fragmentation and transport mechanisms (Dellino and La Volpe 


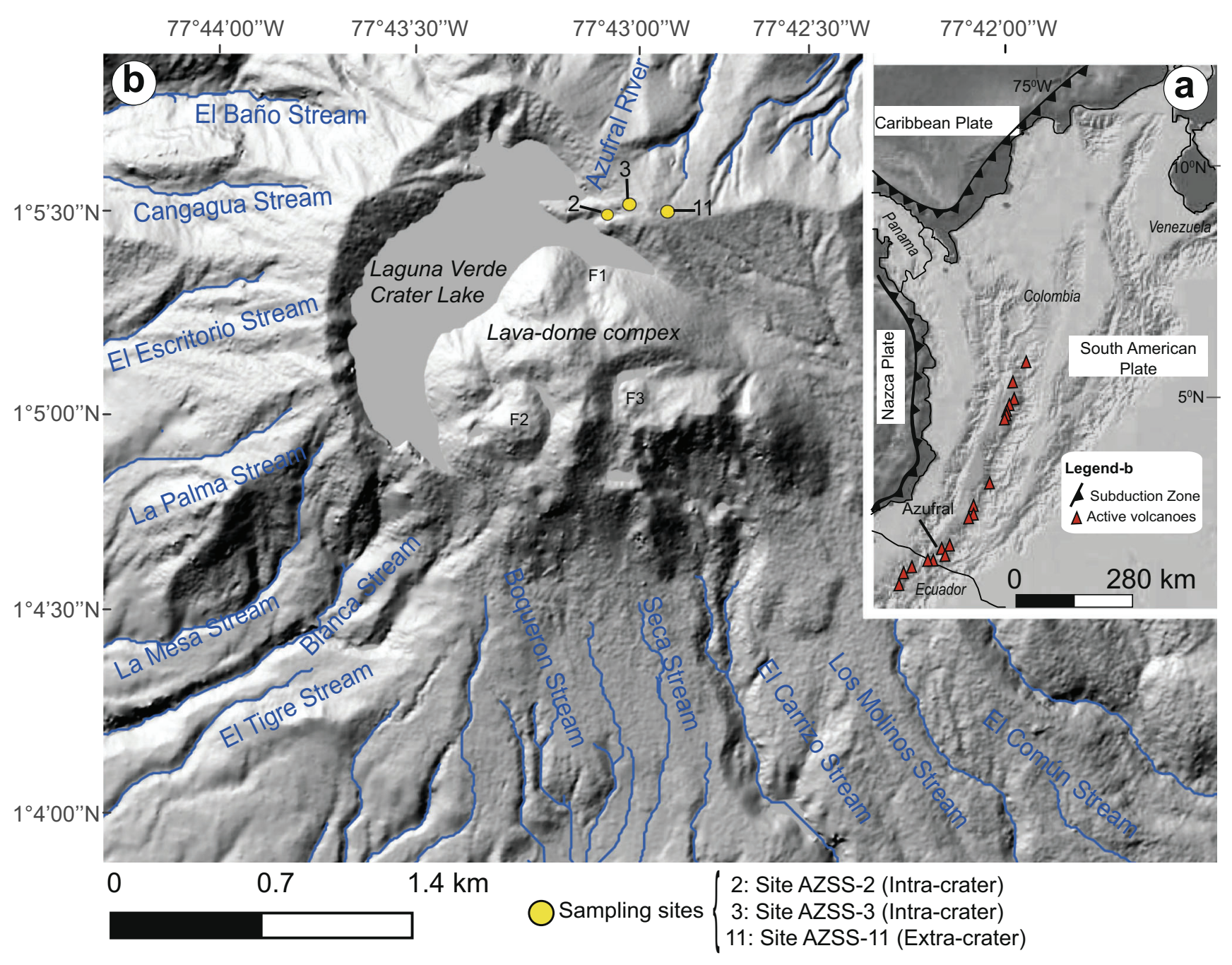

Fig. 1 Study location. a Azufral volcano location in the southern end of the Colombian volcanic arc. b Sample locations on a digital elevation model of the volcano. AZSS-2 and AZSS-3 are part of the same profile

1996a; Dellino and Liotino 2002; Ersoy et al. 2010; Liu et al. 2015; Vonlanthen et al. 2015; Dürig et al. 2012, 2018; Mele et al. 2011; Mele et al. 2018).

Here, we will study the eruption mechanisms leading to fine fragmentation of the Azufral plugs and generation of hazardous dilute pyroclastic density currents. In this study, we provide $2 \mathrm{D}$ morpho-chemical and 2D-to-3D morphometrical and microtextural characterization of ash particles sampled from the youngest-known proximal deposits of dilute PDCs at Azufral, as identified using the previously established stratigraphic and sedimentological framework of Castilla et al. (2018). Our goal is to better understand eruption processes and the potential chronology of events during hazardous explosive eruptions involving interactions with a crater lake. We do this by studying fragmentation mechanisms of high-viscosity magmas, relying on a statistically representative characterization of the fine to very fine ash (2-3 to 3-4 $\phi: 250-63 \mu \mathrm{m})$ and extremely fine ash ( $5 \phi: 63-32 \mu \mathrm{m})$ size fractions. This is done

inside the crater. AZSS-11 is located outside the crater. F1, F2 and F3 are the youngest lava domes (modified from Williams et al. 2017)

by using $2 \mathrm{D}$-automated single-particle analysis with scanning electron microscopy (SEM) coupled to energy-dispersive Xray spectroscopy (EDX) and validated with 3D observations using X-ray microtomography ( $\mu \mathrm{X}-\mathrm{CT})$.

\section{Geological context}

\section{Azufral volcano}

Azufral volcano (4070 $\mathrm{m}$ asl) is located in the Western Cordillera of Colombia and is related to the Nazca Plate subduction underneath the South American Plate (Fontaine and Stix 1993; Droux and Delaloye 1996). Azufral's Holocene explosive history has resulted in the development of a summit crater incised into a $<5$-ka pumice-dominated pyroclastic (mainly ignimbritic) edifice (Calvache et al. 2003). The crater hosts a 30-m-deep, sulphate-rich acidic lake (Carvajal et al. 2008; 

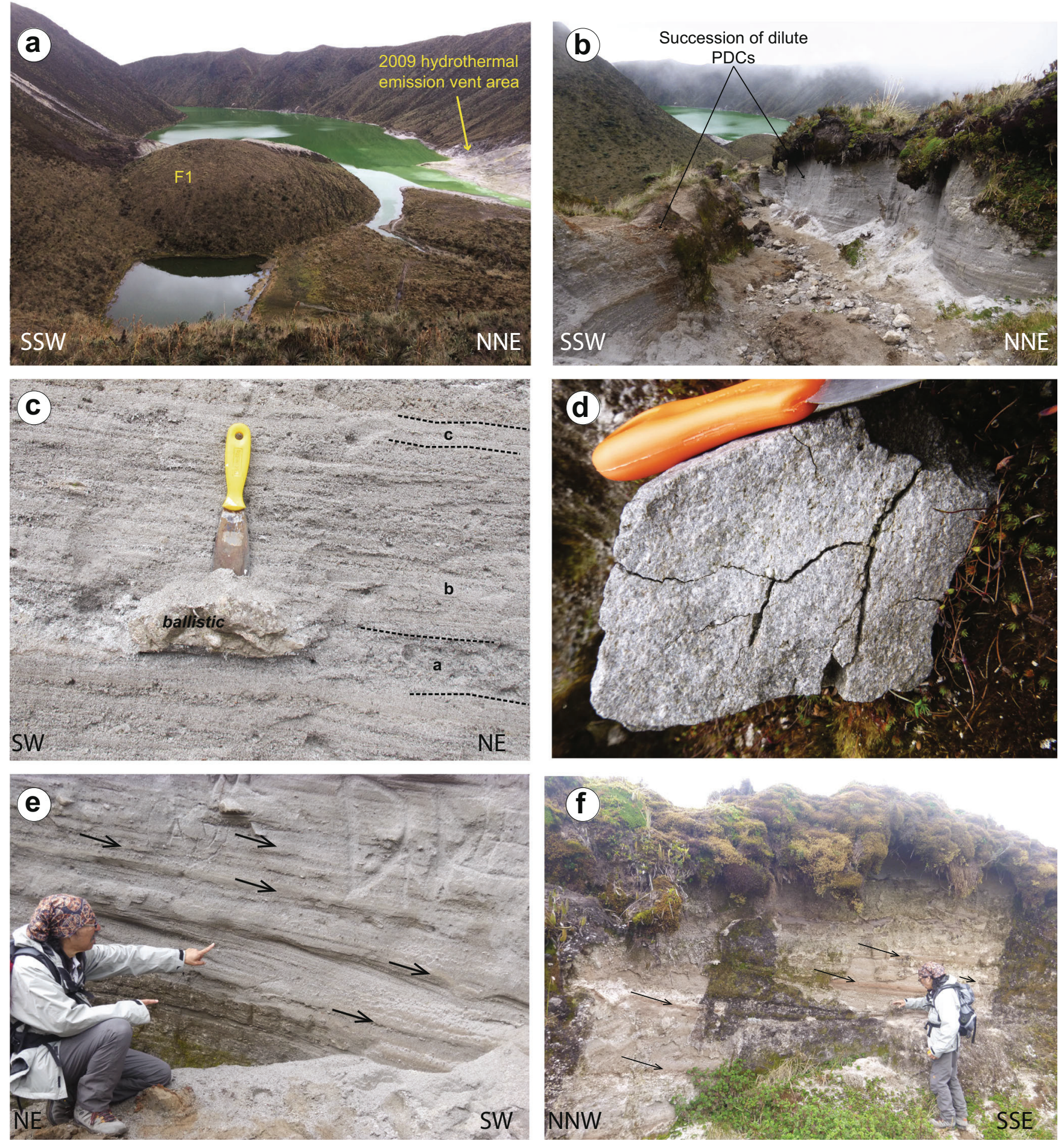

Fig. 2 Field context. a View of the Azufral crater lake and youngest lavadome F1, which diameter in this view is $\sim 150 \mathrm{~m}$. The hydrothermal venting area active in 2009 is marked. b Three to four-m-thick studied outcrops (AZSS-2 and AZSS-3) inside the crater rim. c Example of a complete bed-set (see text for explanations of a-, b- and c-beds); note the pumiceous bomb pointed within the lowermost bed (the spatula is

$20 \mathrm{~cm}$ long). d Breadcrust dense crystalline bomb (the longest axis is 20 $\mathrm{cm}$ ). e Low-angle cross-bedding typical of b-beds, mantled by thin c-type beds (arrows), modified from Castilla et al. (2018). f Studied site outside the crater (AZSS-11). Black arrows in $2 \mathrm{f}$ mark c-type beds capping each bed-set outside the crater. The person is the same in $\mathbf{e}$ and is $1.71 \mathrm{~m}$ tall 
(a) Composite AZSS-2/3

\section{Intra-crater section}

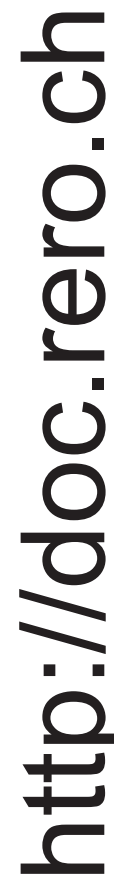

\section{\begin{tabular}{|l} 
So \\
\hline
\end{tabular}}

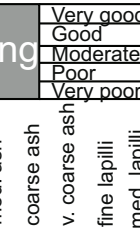

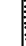
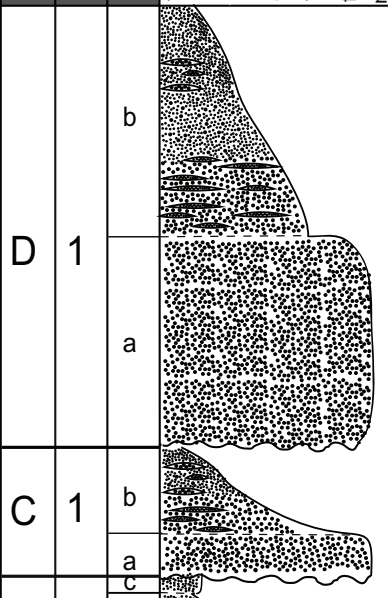

B

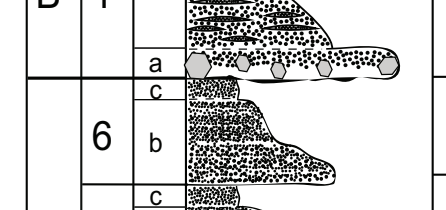

A

5

A 4
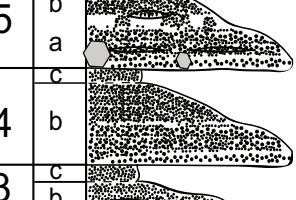

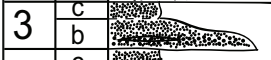

2

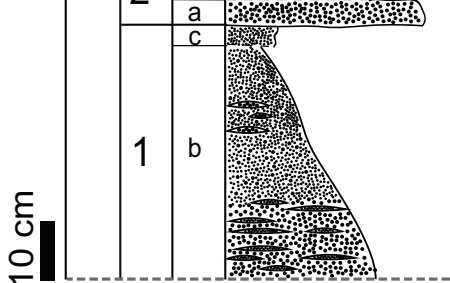

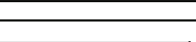
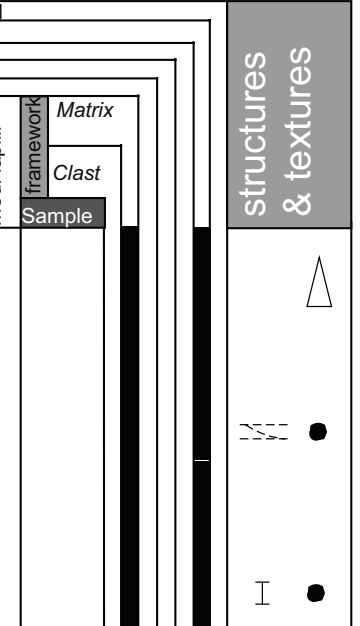

ڤr

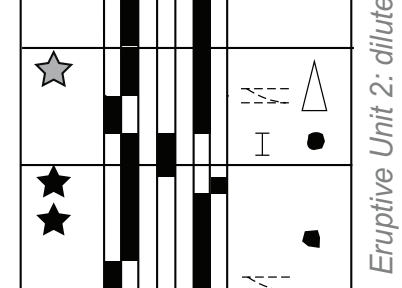

Fig. 3 Stratigraphic profiles of the studied dilute PDC deposits. Left panel (a) shows the best exposed section at site AZSS-2. Sampling positions are shown as black stars. Grey star shows the stratigraphic position of the uppermost c-type bed, which is only locally preserved at

Inguaggiato et al. 2017), and at least four generations of lavadomes characterized by fumarolic emission (Fontaine and Stix 1993; Williams et al. 2017). The last known activity was hydrothermal (Fig. 2a), as reported in 2009 by the Colombian Geological Survey through the Pasto Volcanological and

(b) Site AZSS-11

\section{Extra-crater section}

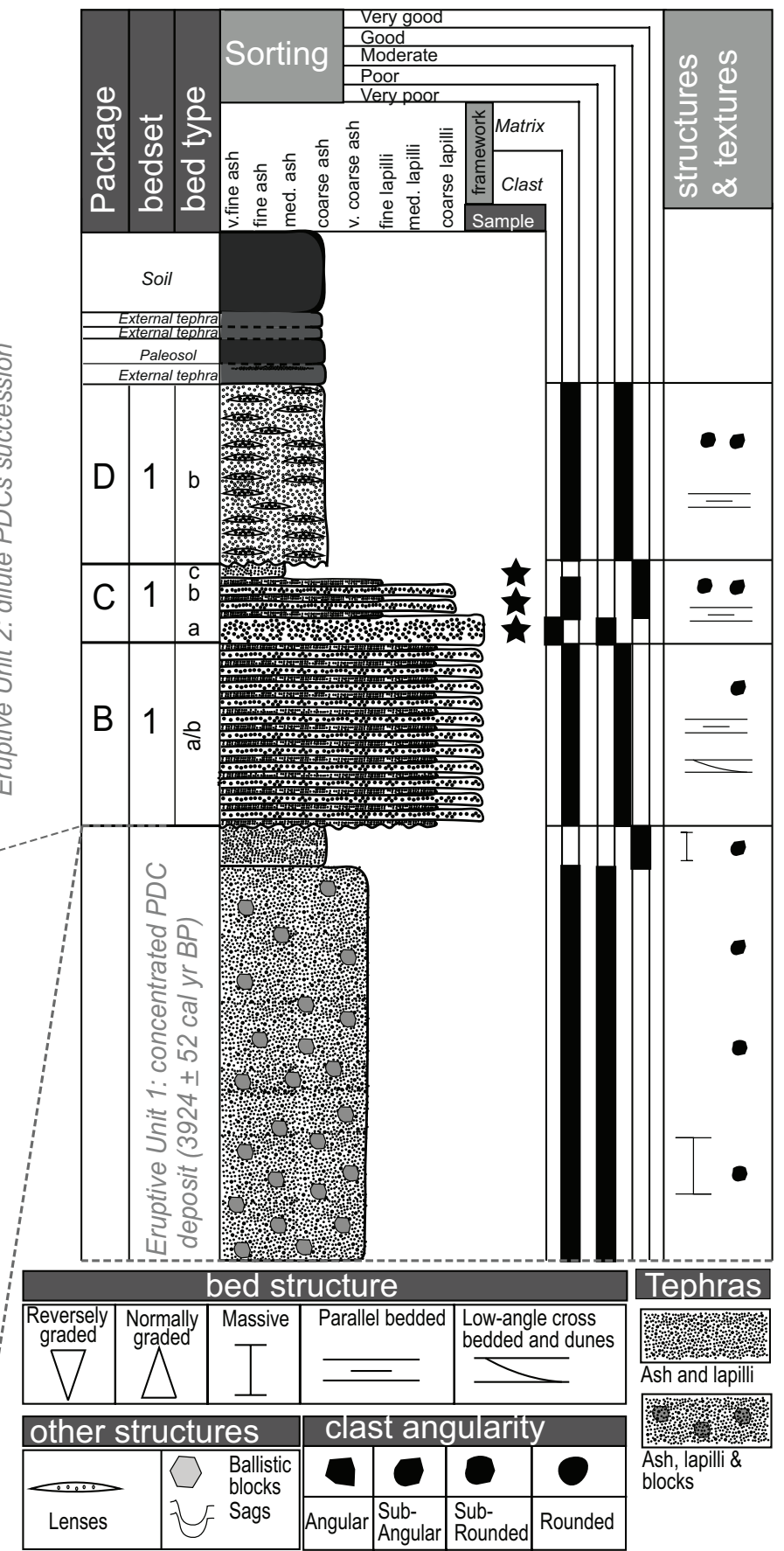

location AZSS-3 (samples 3A-4c; Fig. 1). Right panel (b) shows the profile constructed at site AZSS-11, outside the crater. Modified from the BSc thesis of Sarmiento (2017)

Seismological Observatory (https://www2.sgc.gov.co/sgc/ volcanes/VolcanAzufral/Paginas/default.aspx).

Castilla et al. (2018) detailed the lithofacies associations, petrography and mineral geochemistry of the thickest and youngest proximal succession of dilute PDC deposits at 
Azufral. This pyroclastic succession is thinly bedded and onlaps the north-eastern crater rim, $\sim 130 \mathrm{~m}$ higher than the lake level (Fig. 2b), and this is the unit on which we focus (hereafter termed the "target" unit). Four stratigraphic packages (A-D) are distinguished based on the local concentration of ballistics and erosive surfaces (Fig. 3). Each package within the target unit comprises one or multiple bed sets. On sections exposed on the NE inner crater wall (Figs. 2b, c and $3 \mathrm{a})$, the succession is lithic- and-crystal rich. At the base, each bed-set starts with a variably thick $(6-50 \mathrm{~cm})$, poorly sorted fine lapilli and coarse ash bed showing a basal erosive contact (bed type "a"). Local clast-supported lenses and bread-crusted dense or mostly vesicular bombs are common (Fig. 2c, d). At the top, this a-bed grades into a variably thick (5-60-cm), moderately sorted, parallel and low-angle crosslaminated fine lapilli and ash bed (bed type "b"). In turn, bbeds are mantled by a thin to very thin $(1-5-\mathrm{cm})$, well-sorted, massive or thinly laminated fine-ash bed (bed type "c") (Fig. $2 \mathrm{e})$. In most cases, these uppermost c-beds were eroded by the currents that deposited the overlying bed-set. In general, a-type beds suggest deposition from collision+traction at the highest concentrated zone of the currents, b-type beds indicate important traction+saltation+suspension and c-type beds suggest deposition from suspension within the current's tails (e.g. Vazquez and Ort 2006; Sulpizio and Dellino 2008; Andrews and Manga 2012).

Outside the crater (Fig. 2f), the succession overlaps, with a sharp contact, a pre-existing massive, poorly sorted, highly concentrated PDC deposit (Villamil 2018) hosting charred wood dated to $3924 \pm 52$ years cal BP by Calvache et al. (2003) (Fig. 3). Here, the target unit shows higher pumice clast proportions, thinner and finer-grained beds compared with intra-crater locations.

\section{Petrological constrains of the "target" unit}

Azufral Holocene lava domes and tephras are typical arcrelated, calc-alkaline dacites to rhyolites (Cepeda et al. 1987; Fontaine and Stix 1993; Droux and Delaloye 1996). Ballistic bombs interspersed in the dilute PDC succession are dacites (68.1 to $70.2 \mathrm{SiO}_{2}$ wt.\%, water-free) in bulk composition. Juvenile fragments contain plagioclase $(\mathrm{Pl})+$ amphibole $(\mathrm{Amp})+$ biotite $(\mathrm{Bt})+$ pyroxene $(\mathrm{Px})+$ Fe-Ti oxides + quartz (Qz) assemblages in a variably vesicular to dense, rhyolitic groundmass glass (Castilla et al. 2018). According to Castilla et al. (2018), fractionation of the abovementioned minerals and recharge events mainly controlled the evolution of the erupting magma. Rim compositions of zoned and inherited Pl and Amp microcrysts broadly overlap the composition of the unzoned microcrysts, which provided crystallization temperatures between 988 and $790{ }^{\circ} \mathrm{C}$, pressures between 489 and 68 $\mathrm{MPa}$, and pre-eruptive $\mathrm{H}_{2} \mathrm{O}_{\text {melt }}$ contents between 5 and 9 wt $\%$. In addition, Castilla et al. (2018) estimated minimum decompression rates between $0.6 \times 10^{4}$ and $6 \times 10^{4} \mathrm{~Pa} / \mathrm{s}$ immediately before quenching.

\section{Methods}

\section{Sampling approach}

Ash morphology reflects the pre-eruptive texture of the magma (i.e. the size distribution and volume fraction of crystals and bubbles), as well as fragmentation and post-fragmentation processes (Ersoy et al. 2006, 2007, 2008; Ersoy 2010; Rausch et al. 2015). In order to study variations in the fine to very fine and extremely fine ash componentry and morphology with time, we studied bulk samples of individual beds within complete bed-sets only, at different stratigraphic positions. By doing so, we aim to avoid mixing particles from different transport/depositional regimes.

Inside the crater, two complete bed-sets were sampled within packages A and B (at AZSS-2; Figs. 1 and 3a; samples labelled as $2 \mathrm{~A}$ and $2 \mathrm{~B}$ ). Lamination and bedding are highly discontinuous within package $\mathrm{C}$, which does not contain a complete bed-set. However, a relatively well-preserved c-type bed crops out locally, a few meters to the east, at location AZSS-3 (Fig. 1), which guarantee a sampling-site control (samples 3A-4c) of the uppermost part of the pyroclastic succession before crossing the crater rim.

At the extra-crater site AZSS-11, a complete bed-set within the stratigraphic package $\mathrm{C}$ was sampled (Fig. 3b; samples labelled as 11C), but there are no marker beds allowing an objective correlation of individual packages or bed-sets between intra and extra-crater locations. This situation limits our ability to study variations of individual PDCs over distance. Our findings will therefore be restricted to vertical comparisons between $a-, b-$ and c-type beds of different bed-sets across the studied exposures. Also, the study of the potential effect of the topographical barrier exerted by the crater rim on PDCs transport/deposition will be discussed at the scale of the entire pyroclastic succession and does not reach the resolution of individual beds.

\section{Data acquisition and processing}

\section{Sample preparation}

Each bulk sample was manually dry-sieved into the following size fractions: $2-3$ to $3-4 \phi$, both together $(250-63 \mu \mathrm{m})$ and 5 $\phi(63-32 \mu \mathrm{m})$. The separated size ranges were cleaned multiple times with distilled water, without ultrasound. No hand picking was done prior to mounting, so the studied grains include glassy juvenile clasts, free crystals and lithic fragments. A total of 20 polished thin-sectioned mounts of the bulk $2-3$ to $3-4 \phi$ and the $5 \phi$ size ranges of samples shown 
in Fig. 3 were prepared and carbon-coated for SEM analysis of particle cross sections. It is crucial that individual particles of each mount are sufficiently separated from each other to guaranty their analysis as individual and not aggregated particles. One major advantage at analysing two size fractions on the same thin-sectioned mount is that the subsequent analysis and data treatment is more efficient and cost-effective. It must be taken into account that for all following evaluations that considered particle size, their equivalent circular diameter (ECD) measured with the AZtecFeature analysis software (COxford Instruments) was used. Grains finer than $5 \phi$ were not examined because the manipulation and preparation of individual grains (required for image analysis) of such extremely fine material is very complex.

\section{Automated SEM/EDX particle analysis of multiple particles}

The 2D-automated single-particle SEM/EDX imaging and analysis (Laskin and Cowin 2001)_also known as CCSEM (computer-controlled SEM) - was performed at the Particle Vision laboratory (Fribourg, Switzerland). A Zeiss GEMINI 300 Field Emission Gun (FEG)-SEM coupled with an X-Max EDX-detector equipped with an $80-\mathrm{mm}^{2}$ window, under $20 \mathrm{kV}$ and a $60-\mu \mathrm{m}$ aperture (approx. $20 \mathrm{nA}$ ), was used. Image pixel size for the analysis of the 2-3 to 3-4 $\phi$ range was 0.37 micron $(\times 150$ magnification and resolution of 2048 $\times 1536$ pixels per image), while the pixel size for the $5 \phi$ fraction was 0.19 micron $(\times 300$ magnification and $2048 \times$ 1536 pixels per image). Particles were recognized by grey value (i.e. BSE intensity) thresholding. Between 276 and 1277 (mostly > 600) particles were measured per sample. A raster of EDX analysis was performed for each recognized particle, delivering the elemental bulk composition per particle. The recognition of individual particles and subsequent elemental analysis and imaging was performed with the aid of the AZtecFeature analysis software (COxford Instruments).

\section{SEM/EDX data processing and particle discrimination}

The SEM-EDX chemical data of each particle (Online resource 1.1) was subsequently processed with a modelbased two-stage particle classifier software (Meier et al. 2018) and transformed into a heatmap, which is a graphic illustration of the major element average chemical composition (wt $\%$ ) of individual particles grouped into chemical classes. The obtained chemical data for glass and minerals was also plotted in a ternary diagram and compared with the quantitative electron probe micro analysis (EPMA) data reported by Castilla et al. (2018) to check consistency (Online resource 1.2). Furthermore, the backscatter electron (BSE) image of each field of analysis $(2048 \times 1536$ pixels $)$ were assembled in one cohesive image in order to merge incomplete particles located in adjacent fields and exported as an individual .tiff with AZtecFeature. Rounded and subrounded particles were included for componentry but excluded from morphometry to reduce the effect of secondary fragmentation. The $2 \mathrm{D}$-imaged particles with equivalent diameter smaller than $50 \mu \mathrm{m}$ for the 3-4 $\phi$ fraction, and smaller than $25 \mu \mathrm{m}$ for the $5 \phi$ fraction, were digitally removed from the resulting dataset to exclude particle edge artefacts, following Rausch et al. 2015.

Overall componentry For componentry, particles must be organized into classes including lithics, crystals and glassy juvenile grains. The first discrimination filter is based on an automatic grouping of particles purely based on their chemical composition obtained from the semi-quantitative SEMEDX analyses and visualized in the form of a heatmap (Online resource 1.2). This first step allows the fast discrimination of most free and slightly glass-coated crystals (except for feldspars) owing their distinct chemical composition compared with the other particles/components. For feldspars, we double-checked the molar content of each element within each crystal to avoid potential misclassification of these components as glass. Juvenile glassy and accessory lithic particles (i.e. devitrified, corroded and/or altered glass, microcryst-rich lithics and secondary minerals derived from the conduit walls and hydrothermal system; Nurfiani and de Maisonneuve 2018) show an important overlap in averageparticle chemistry. This made their discrimination on a chemical basis impracticable. To distinguish them, we manually examined their BSE images. In this second filtering step, the juvenile glassy particles were distinguished from accessory lithic fragments based on their relatively smooth groundmass microtextures with nearly homogeneous greyscales. They can, however, exhibit small heterogeneities related to their microcryst and vesicle content, but they clearly lack evidence of devitrification or alteration, which are commonly expressed in heterogeneous greyscales (e.g. greyscale standard deviation). Accessory lithic particles show multiple/heterogeneous greyscales and highly complex microtextural patterns related to devitrification, oxidation and corrosion of the groundmass. Some show secondary sulphides.

Moreover, particles exhibiting more than $50 \%$ of their area occupied by a particular crystal and coated by fresh (smooth greyscale) glass were classified within their corresponding freecrystals mineral group. Otherwise, the glass-dominated (> 50\%) ash particle was included into the corresponding juvenile glass type. If the coating material exhibited a devitrified or corroded inner microtexture as mentioned above, the particle was included into the accessory lithic group. We acknowledge that this is an important assumption because some of the dense, devitrified or altered lithic fragments could also derive from degassed portions of the plug. However, we count them as accessory because these particles lost their original morphology and texture and 


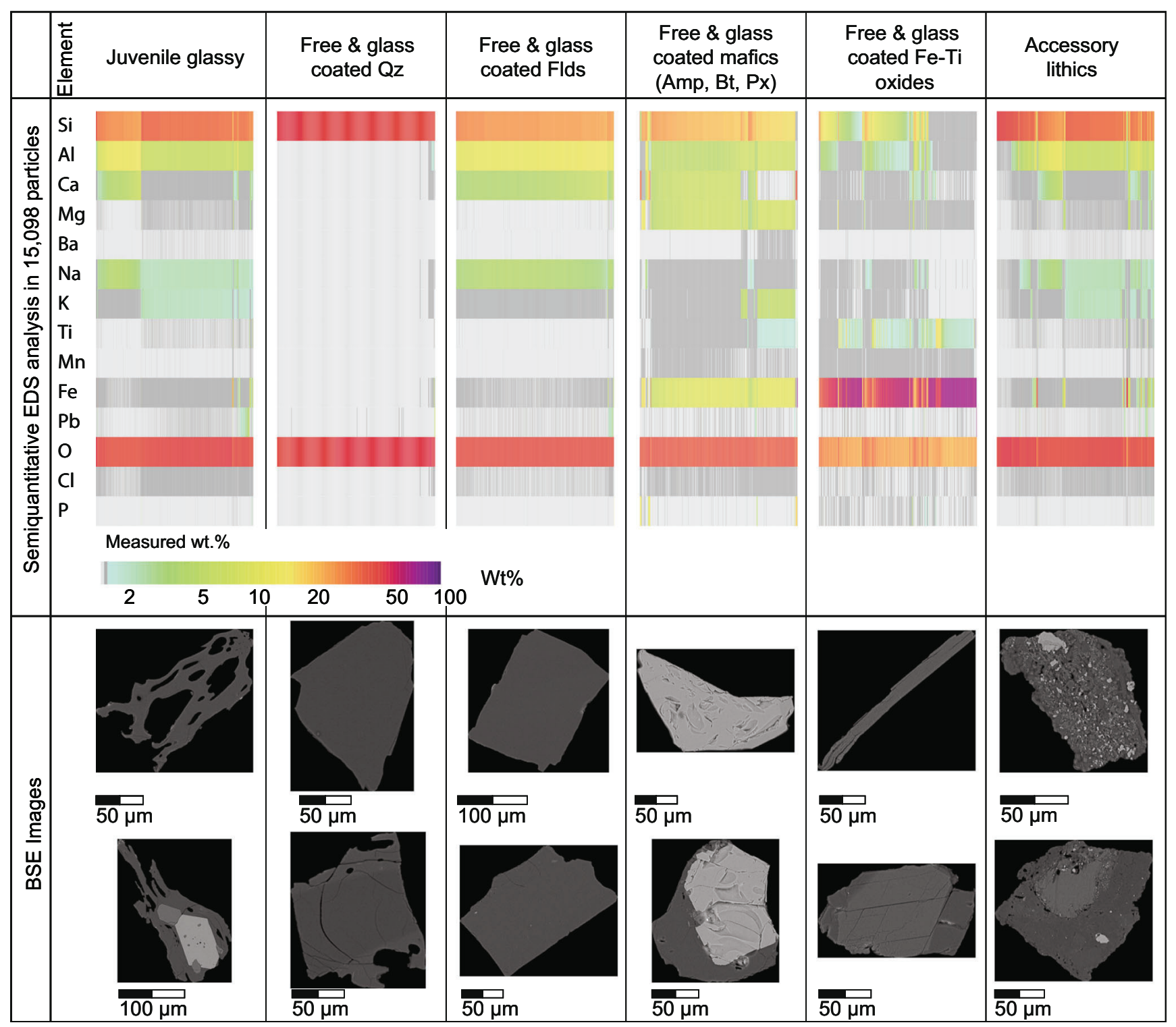

Fig. 4 Chemically and microtexturally classified heatmap of all fine to extremely fine ash particles analysed ( $n=15,098)$. Each vertical line corresponds to the element (wt.\%) average composition of a single particle (see the colour bar for relative abundance of each chemical element)

therefore cannot be used to accurately infer fragmentation mechanisms (Nurfiani and de Maisonneuve 2018).

After the automated (i.e. chemical) and successive manual (i.e. microtextural) filtering, we re-classified the particles into (i) juvenile glassy particles, (ii) free and glass-coated crystals and (iii) accessory lithic particles (Fig. 4).

Groups of juvenile particles Once juvenile glassy particles were separated from accessory particles and crystals, the BSE images of the single glassy particles obtained with AZtecFeature ( ${ }^{@}$ Oxford) were further analysed with ImageJ ( ${ }^{@}$ NIH-Schneider et al. 2012) aiming to further discriminate groups of juvenile particles (third filtering step). The form (e.g. axial ratio), morphological (area-based) roughness (e.g. solidity) and textural (perimeter-based) roughness (e.g. convexity) parameters were calculated, using the macro provided in Liu et al. (2015) (Table 1; Online resource 2.1). Initially, we plotted convexity vs. solidity, following the recommendations of Liu et al. (2015) (Fig. 5a), but significant overlap occurs between morphological groups. The 26 morphometry parameters obtained for each glass particle (Online resource 2.1) were processed with a principal component analysis (PCA) algorithm (Ringnér 2008; Nurfiani and de Maisonneuve 2018). We used R software (Core Team 2013) to plot the distribution of the variance between ash grains in a vector space. The PCA plots (Online resource 2.2) allowed the identification of the best discriminators of juvenile subclasses (Fig. 6). This involved a combination of (i) area-based roughness parameters (i.e. solidity and defect area, dependent on particle-scale concavities), (ii) perimeter-based roughness 


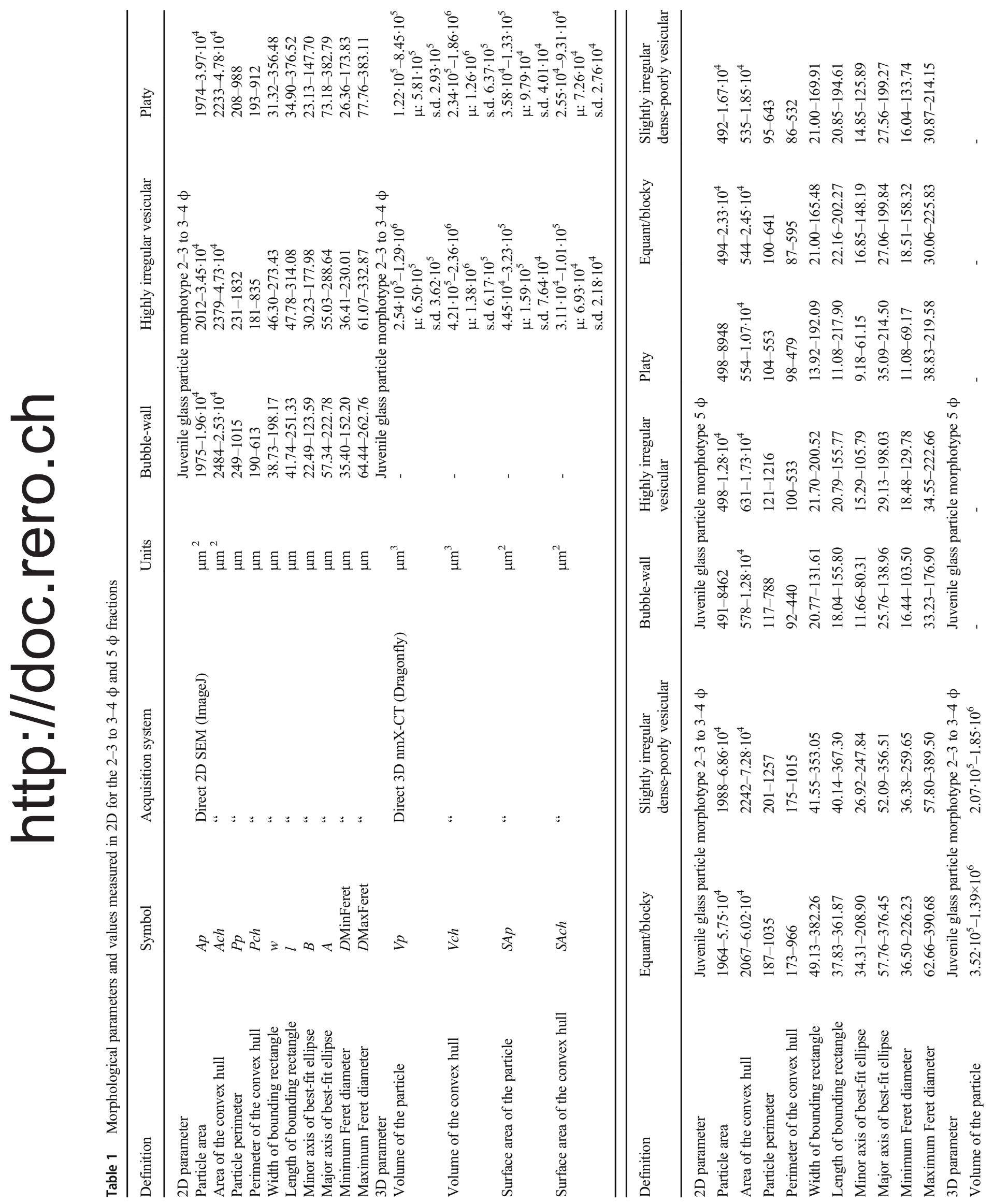


parameters (i.e. Convexity, Paris Factor and Convexity Ferret, dependent on small-scale concavities) and (iii) form parameters (Aspect Ratio, Axial Ratio and Form Factor, dependent on the overall elongation of the particle), plus (iv) the Concavity Index (Tables 1 and 2; Online Resource 2.1). A last manual revision (one particle at a time) of smaller groups of .tiff files was carried out to solve particles falling into remaining overlapping fields on the PCA plots (roughly 5-7\% of the total particles), leading to the final classification (Fig. 4) and quantification (Tables 2 and 3; Fig. 7).

\section{X-ray microtomography $(\mu \mathrm{X}-\mathrm{CT})$}

To validate the 2D (cross-section) observations on juvenile particles and to consider sectioning effects, a subsample of the 3-4 $\phi$ size range of the c-type bed of each bed-set was mounted in a less than 2-mm-thick cylinder of dental wax for analysis with micro X-ray computed tomography ( $\mu \mathrm{X}-\mathrm{CT}$ ). The study of the c-beds allowed us to compare similar layers at different stratigraphic positions, minimizing abrasion and secondary fragmentation effects.

The 3D imaging of the external morphology and roughness, as well as the inner microtexture, was obtained with a multiscaled Bruker-SkyScan $2211 \mu \mathrm{X}-\mathrm{CT}$ at the University of Fribourg (Switzerland). The shadow images $(0.33-\mu \mathrm{m}$ pixel size) were taken under an X-ray voltage of $65 \mathrm{kV}$ and $300 \mu \mathrm{A}$ of current, at a rotation step of $0.2^{\circ}$. Cross-section images have been reconstructed using Bruker-SkyScan NRecon software (program version 1.6.9.18). Image smoothing (Gaussian using a radius of 3 pixels, erosion and dilation) and cutting of individual particles were performed with CTAn software (SkyScan 2009). Each particle was then segmented, measured and rendered with Dragonfly 4.0 software (@Object Research Systems Inc., Montreal, Canada). For 3D-Convex Hull computation, and 3D-Convexity and 3D-Solidity calculations, we followed Sheets et al. (2011) and used their 3D plugin in ImageJ. In total, 115 intact particles could be isolated and quantitatively analysed, 51 of which corresponded to juvenile glass particles (Online Resource 3.1). The latter were compared with the main 2D roughness descriptors (Fig. 5b; Table 2). In order to segment internal closed bubbles and calculate their dimensions, each BSE image was binarized (image A). Holes were digitally filled with thresholding (image B). By substracting B-A, closed bubbles were extracted and measured. Their vesicularities follow Houghton and Wilson's (1989) index. Also, virtual orthoslices allowed comparison of particle shapes and inner microtextures with the 2D BSE images. In this way, the continuous iteration between 2D and 3D observations throughout the study favoured the best approach for an objective glass particle discrimination (Fig. 6). 


\section{Results}

The high degree of automatization of the 2D particle analysis allowed fast and accurate chemical analysis and imaging of 15,098 fine to extremely fine ash particles (Online Resource 1.1; Table 3) after removing all artefacts. Furthermore, we obtained the morphometric data (Tables 1 and 2) of 4895 juvenile glassy particles (Online resource 2.1). The resulting heatmap after the first and second filtering/classification steps (Fig. 4) and juvenile subdivisions obtained after the third classification step (Figs. 5 and 6) provided reliable information on the 2-3 to 3-4 $\phi$ and $5 \phi$ componentry through the stratigraphic profiles (Fig. 7; Table 3). Below, we first address the overall componentry variations, followed by the subdivision of juvenile glassy particles into groups.

\section{Overall componentry}

Fine to extremely fine ash particles range from crystal-lithic to vitric-lithic (following the Cook (1965) classification). They occur in well-mixed layers of nearly equal proportions of juvenile glassy, crystal and accessory lithic particles, without deep-seated accidental lithics (Fig. 7a; Table 3; Online Resource 1.1). The quantified free crystals or crystals showing a thin glass coat are mostly feldspars, followed by mafics (amphibole $>>$ biotite $>$ pyroxene), Fe-Ti oxides and quartz in all beds (Fig. 7b; Table 3; Online Resource 1.1).

In general, accessory lithic particles proportions are 25-40 vol. $\%$ in the $2-3$ to $3-4 \phi$ fraction and $30-45$ vol. $\%$ in the $5 \phi$ fraction inside the crater. Outside the crater, accessories represent 40-52 vol.\% and 31-55 vol.\%, respectively. Except for the uppermost $3 \mathrm{~A}-4 \mathrm{c}$ bed, which will be discussed below, free and glass-coated crystals range from 31 to 51 vol.\% (2-3 to 3$4 \phi)$ and from 27 to 37 vol.\% (5 $\phi)$ inside the crater, whereas outside the crater, crystal contents span 11-27 vol.\% (2-3 to 3-4 ф) and 11-21 vol.\% (5 ф). In contrast, juvenile glassy particles range from 19 to 31 vol.\% (2-3 to 3-4 $\phi)$ and 28-39 vol.\% (5 $\phi$ ) inside the crater, and 33-36 vol.\% (2-3 to 3-4 $\phi)$ and 32-49 vol.\% (5 ф) outside the crater (Fig. 7a; Table 3). By comparing all fine-very fine vs. extremely fine ash components, accessory lithics and juvenile glassy particles slightly increase (whereas crystal content decreases) in the $5 \phi$ fraction for most beds.

\section{Vertical and lateral componentry changes}

In general, accessory lithics inside the crater are less abundant than in b- and c-type beds outside the crater. Inside the crater, the lowest lithic contents were found in the b-type beds and lithic content generally increases with stratigraphic position when comparing similar bed types of different bed-sets (Online Resource 1.11). The lowermost a-type bed outside the crater $(11 \mathrm{C}-1 \mathrm{a})$, which represents the base of the $\mathrm{C}$
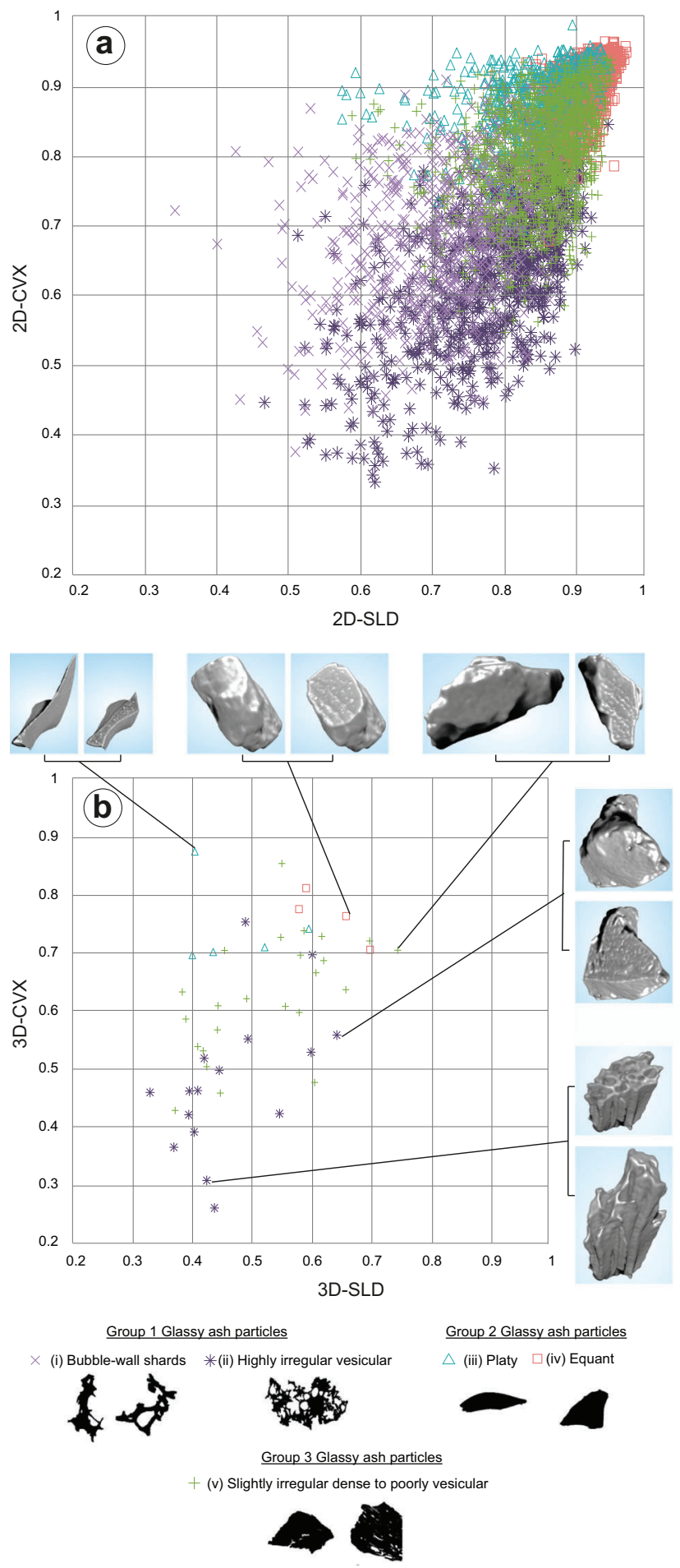

Fig. 5 2D (a) vs. 3D (b) comparison of solidity (SLD) and convexity (CVX) values

package there, has lower accessory lithic content compared with the overlying beds (Fig. 7a).

Intra-crater beds, except for the uppermost $3 \mathrm{~A}-4 \mathrm{c}$ bed, show relatively higher crystal contents than all extra-crater beds (Fig. 7a; Table 3). Among crystals, all (but the 3A-4c) intra-crater beds are mafic-poor but feldspar-rich compared 

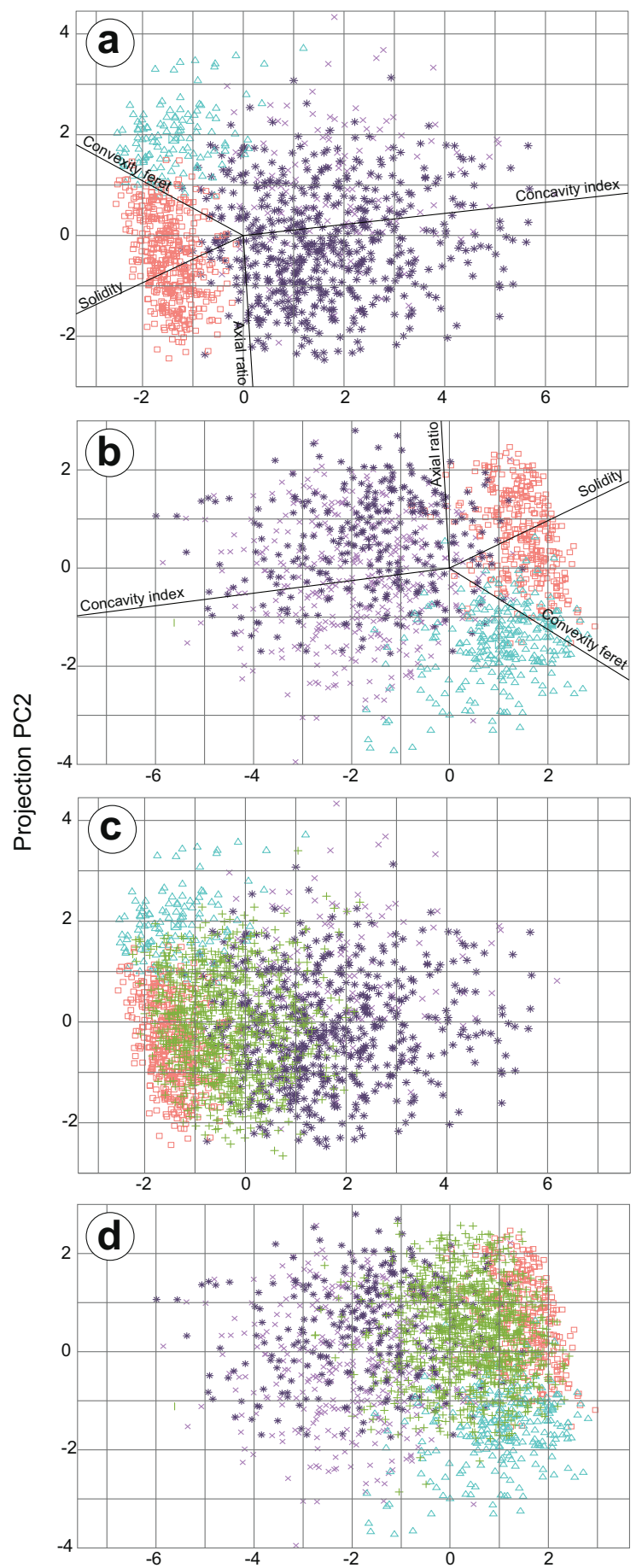

Projection PC1

Group 1 Glassy ash particles

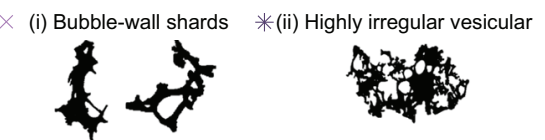

Group 2 Glassy ash particles Group 3 Glassy ash particles $\triangle$ (iii) Platy $\square$ (iv) Equant $\quad+$ (v) Slightly irregular dense

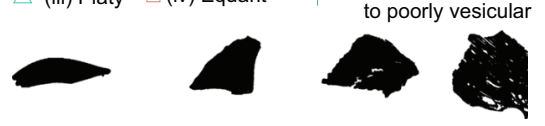

Fig. 6 2D principal component analysis of the glassy fine to extremely fine ash particles, using the obtained shape parameters (scaled from 0 to 1). Juvenile glass endmember groups 1 and 2 shown for a 2-3 to 3-4 $\phi$ and $\mathbf{b} 5 \phi$. Group 3 particles showing intermediate roughness given in $\mathbf{c}$ $2-3$ to $3-4 \phi$ and $\mathbf{d} 5 \phi$ fractions

with extra-crater beds (Fig. 7b; Table 3; Online Resource 1.1.2). In addition, the total glass content is slightly lower inside the crater than most extra-crater beds (Online Resource 1.1.1).

The uppermost $3 \mathrm{~A}-4 \mathrm{c}$ bed is atypical compared with the underlying beds inside the crater and is distinguished by a marked peak in glass content while showing the lowest crystals content. In fact, the $3 \mathrm{~A}-4 \mathrm{c}$ bed bulk and crystal componentry are similar to that of samples outside the crater (Fig. 7a, b).

\section{Glassy particle groups}

The groups of particles identified with the 2D and 3D data are illustrated on the convexity vs. solidity plot for comparative purposes (Fig. 5). Although fewer particles could be processed in 3D (Fig. 5b; Online resource 3.1), the $\mu \mathrm{X}-\mathrm{CT}$ data show a similar relative position of the different fields seen in the 2D analysis (Fig. 5a). The absolute values, however, differ due to sectioning effects or due to potential errors in the 3DConvex Hull computations, particularly in the surface area estimation between small pixels (Online resource 2.1; Table 2).

The glassy ash particles were subdivided into three main groups based on PCA plots (Fig. 6) and manual verification. One end-member group (group 1) comprises highly irregular shards with outlines showing indentations and concavities which result in high roughness, with solidity and convexity values spanning towards low values (Fig. 5). These particles have $2 \mathrm{D}$ solidity as low as $0.34,2 \mathrm{D}$ convexity as low as 0.33 and 2D convexity-ferret values as low as 0.37 (Table 2; Online Resource 2.1). Also, 3D solidity and 3D convexity values are as low as 0.33 and 0.26 , respectively (Online Resource 3.4; Table 2). This group includes two classes: (i) bubble-wall shards and (ii) highly irregular, moderately vesicular particles (Figs. 5 and 6). The discrimination between (i) and (ii), however, is strictly qualitative in $2 \mathrm{D}$, based on the manual filtering (one particle at a time), because they show large overlapping morphometry (Fig. 6; Online Resource 2.1 and 2.2). In fact, while observing the particles in 3D (Online Resource 3.1), all bubble-wall shards and highly irregular vesicular shards merge into one single category, given that some of the former could be transversal sections, or smaller portions of, the latter.

The other endmember group (group 2) consists of dense (non-vesicular to incipiently vesicular), smooth glass fragments of low roughness, with nearly straight outlines and 


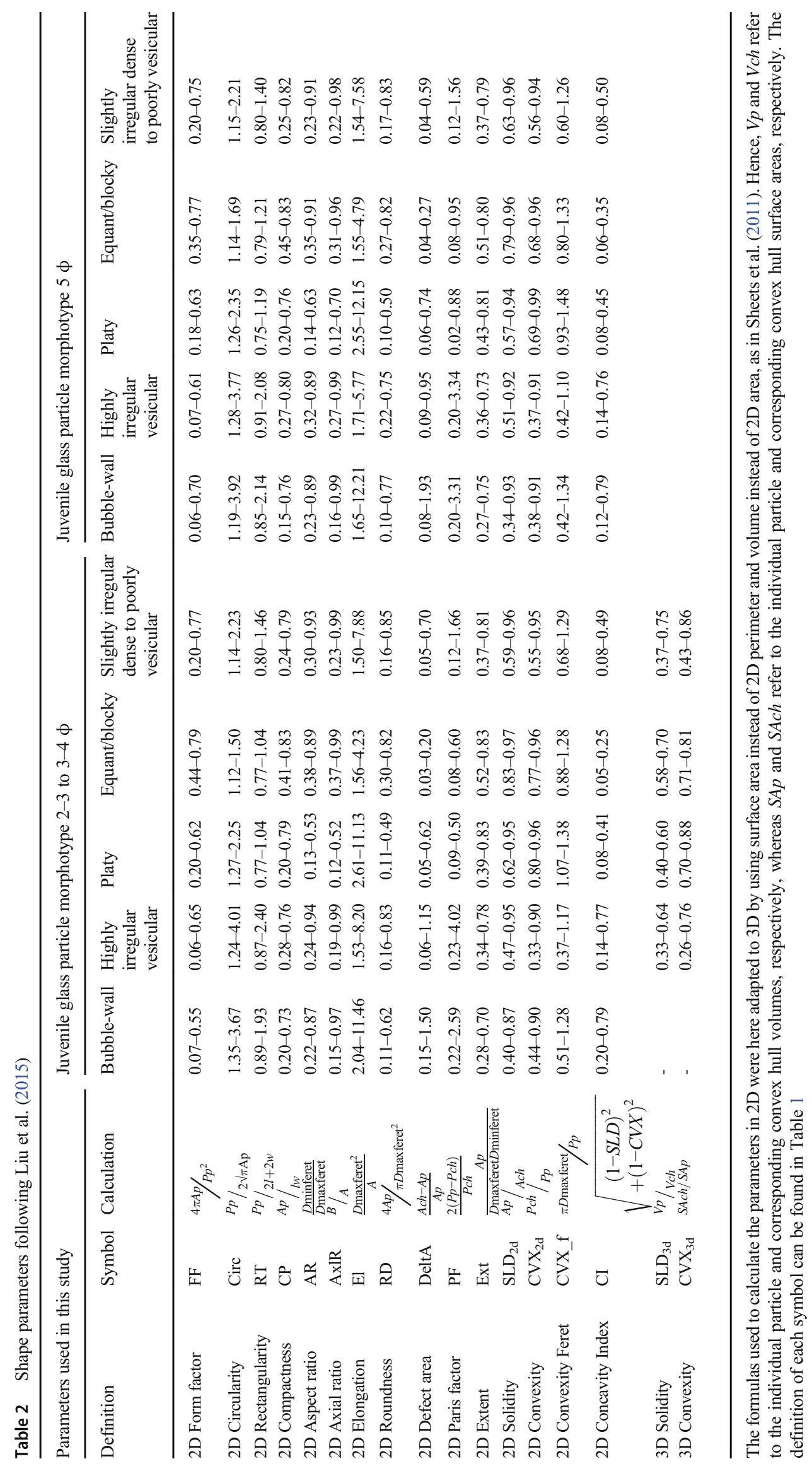




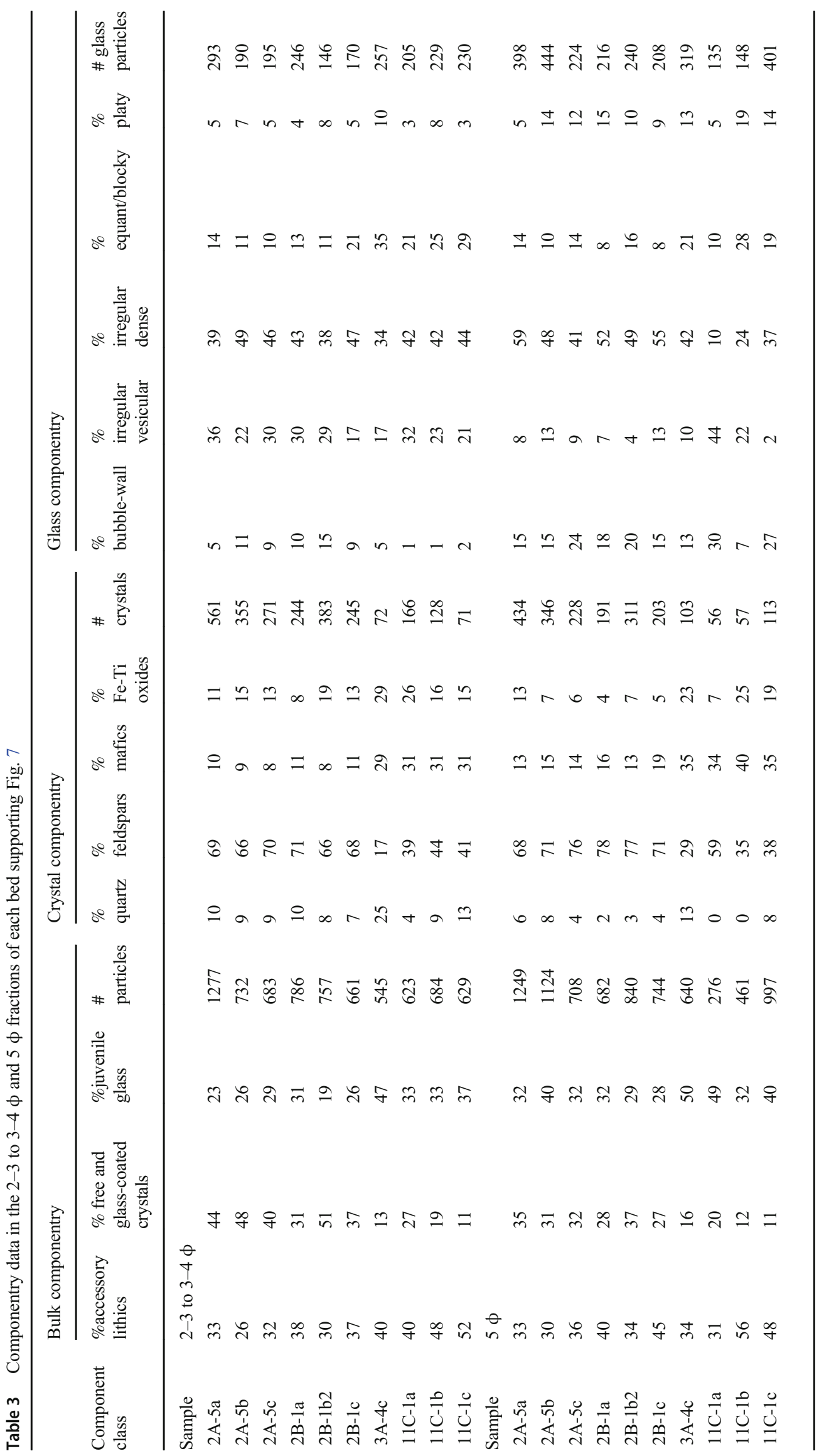




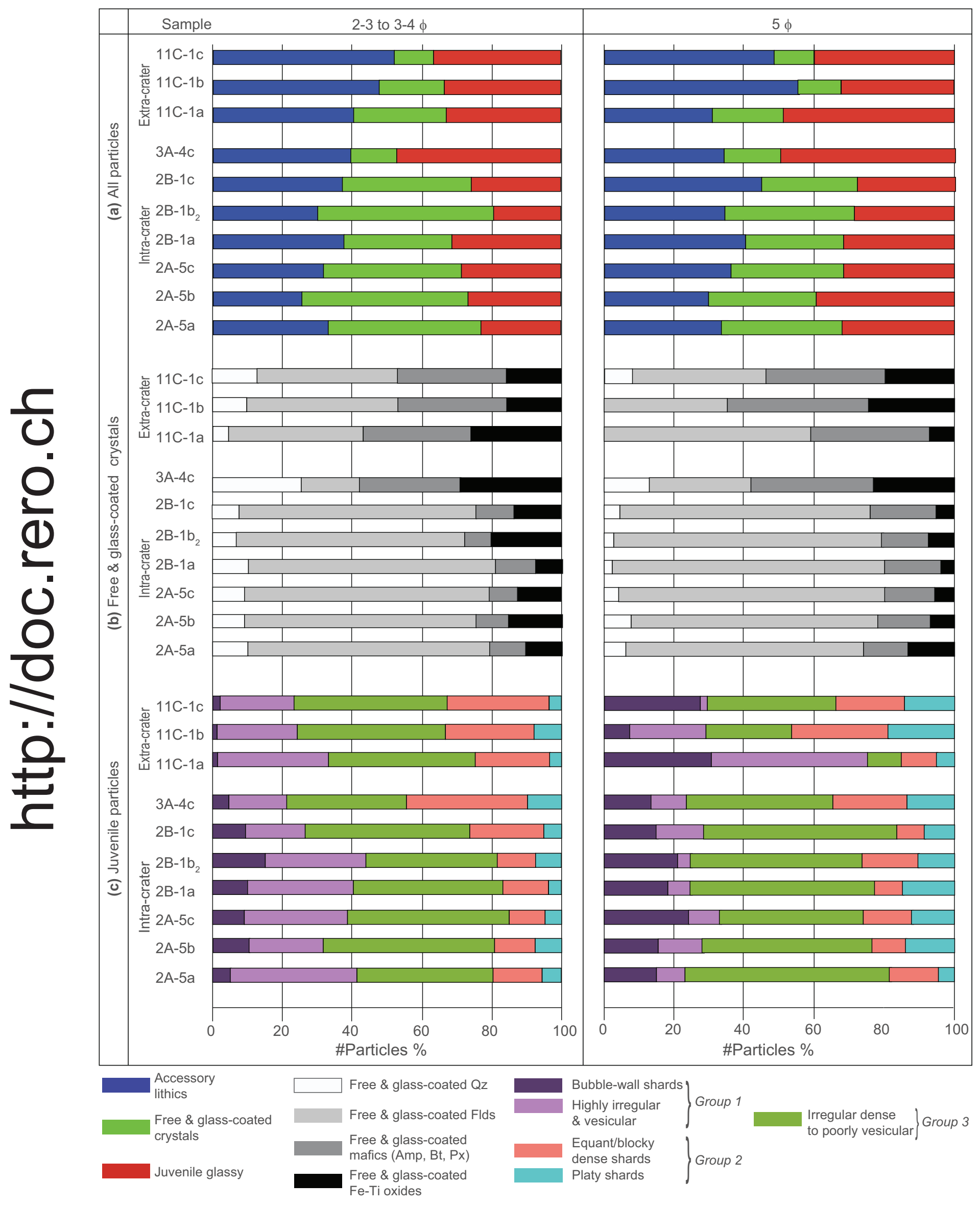


4Fig. $72 \mathrm{D}$ componentry of fine to extremely fine ash in the studied profiles. See the lithic-crystal-juvenile glass relative proportions in the uppermost panels (a) and the relative proportions of each crystal type in the intermediate panels (b). For the relative proportions of each juvenile class, see the lowermost panels (c)

sharp angles between faces. These dense particles cluster within the high solidity and convexity field (Fig. 5) and were subdivided with the PCA, followed by manual verification of each BSE image (Fig. 6; Online Resource 2.2) into two classes: (iii) platy-shaped shards and (iv) equant/blocky glass fragments. Some of the latter show a few vesicles and peripheral microcracks perpendicular to the outline. The blocky/equant glass shards have $2 \mathrm{D}$ solidity $>0.79$, convexity $>0.68$ and convexity-ferret values $>0.80$ (Table 2; Online Resource 2.1). The $3 \mathrm{D}$ solidity values are typically $>0.58$ and $3 \mathrm{D}$ convexity values $>0.71$ (Online Resource 3.4; Table 2). When observed in 3D (Online Resource 3.2), a few equant/blocky and platy shards in the fine-very fine ash fraction also merge into one single category, indicating that sectioning effects are plausible.

An excellent descriptor discriminating these two contrasting endmember groups is the 2D Concavity Index (Table 2; Online Resource 2.1; Fig. 6), which is higher in the first group of particles $(0.14-0.77)$, than in the second one $(0.05-0.35)$, even though a small overlap occurs.

Finally, there is a group of particles with intermediate roughness values (group 3, or class v). It comprises slightly irregular glass fragments, spanning from non-vesicular to incipiently vesicular, largely overlapping the other groups (Fig. 6c, d; Online Resource 3.3).

For the juvenile glass componentry (Fig. 7c; Online Resource 1.1.3), the $5 \phi$ fraction of all intra-crater beds shows higher relative contents of group 3 particles and slightly lower relative contents of group 1 particles, compared with extracrater beds. The $3 \mathrm{~A}-4 \mathrm{c}$ bed is particularly rich in group 2 (blocky and platy) juvenile clasts, especially in the 2-3 to $3-$ $4 \phi$ fractions.

\section{Impact of vesicles on juvenile particle shapes}

We confirm a strong relationship between juvenile clast shapes and internal textures, as seen elsewhere by Mele et al. (2018). Most of the particles with high roughness (group 1) are asymmetrical, with the major axis being nearly parallel to the orientation of external surface "channels", which are imprints of tube-like vesicles larger than the measured particles (Fig. 5b). Fewer symmetrical particles show a spongyfibrous surface texture given by smaller but numerous tubelike vesicles. In both cases, internal vesicles are mostly isolated and range from small $\left(<10 \mu \mathrm{m}^{3}\right)$ to medium-sized $(\sim 10$ $30 \mu^{3}$ ) subspherical to larger, nearly parallel ellipsoidal shapes. Ellipsoidal vesicles range in shape from flattened- prolate, to sheared (some coalesced), prolate, and a few very flattened and irregular (Online Resource 3.1). Very few of the medium-sized subspherical vesicles show irregular inflations (i.e. coalesced).

Most of the particles with low roughness (group 2) observed with the $\mu \mathrm{X}-\mathrm{CT}$ are consistently dense (Fig. 5b), and their 3D shape is confirmed to be related to the intersection of nearly planar surfaces. The very few vesicles present are flattened-oblate or small subspherical (Online Resource 3.2). Finally, particles of intermediate roughness values (group 3) show smooth planar to concave surfaces with local indentations. Inner vesicles are mostly flattened and very irregular, locally evolving into highly interconnected paths (Online Resource 3.3).

\section{Discussion}

We obtained robust chemical and morphological data on several thousands of fine to extremely fine ash particles. The chemical bulk composition of individual glass and mineral particles is comparable with quantitative EPMA spot data (Online Resource 1.1) and facilitates the classification of the components using large, rapidly generated datasets. Once BSE images of glassy particles are separated through successive automatic and manual interactions, a PCA facilitates the morphometry discrimination of groups (Online Resource 2.1). The 3D $\mu \mathrm{X}-\mathrm{CT}$ data provides control on sectioning effects and information on internal microtextures (Online Resource 3.1).

Based on these data, we propose an eruptive model for the targeted Azufral deposits (Fig. 8) which starts with viscous magma rising under the crater lake, forming an incipient plug at relatively shallow depth. The plug is then fragmented by internal (magmatic) and phreatomagmatic processes. This creates dilute PDCs deposits. We discuss each of these steps in turn.

\section{Initial conditions and plug development}

The absence of a paleosol between the studied succession and the underlying $3924 \pm 52$ cal year BP unit suggests a relatively short time between both stratigraphic units. However, a repose time between eruptions was long enough to form an incipient plug and establish a sharp contact of higher hierarchical order compared with intra-unit contacts. An incipient plug (Fig. 8a) would retain the characteristics of juvenile glass following densification (Wadsworth et al. 2018). This is revealed by similarly high (5 and $8 \mathrm{wt} \%$ ) pre-eruptive $\mathrm{H}_{2} \mathrm{O}_{\text {melt }}$ contents measured in the predominant vesicular bombs' groundmass and in the vesicular glassy ash particles (Castilla et al. 2018). Hence, most of the plug was subjected to only to a few cycles 


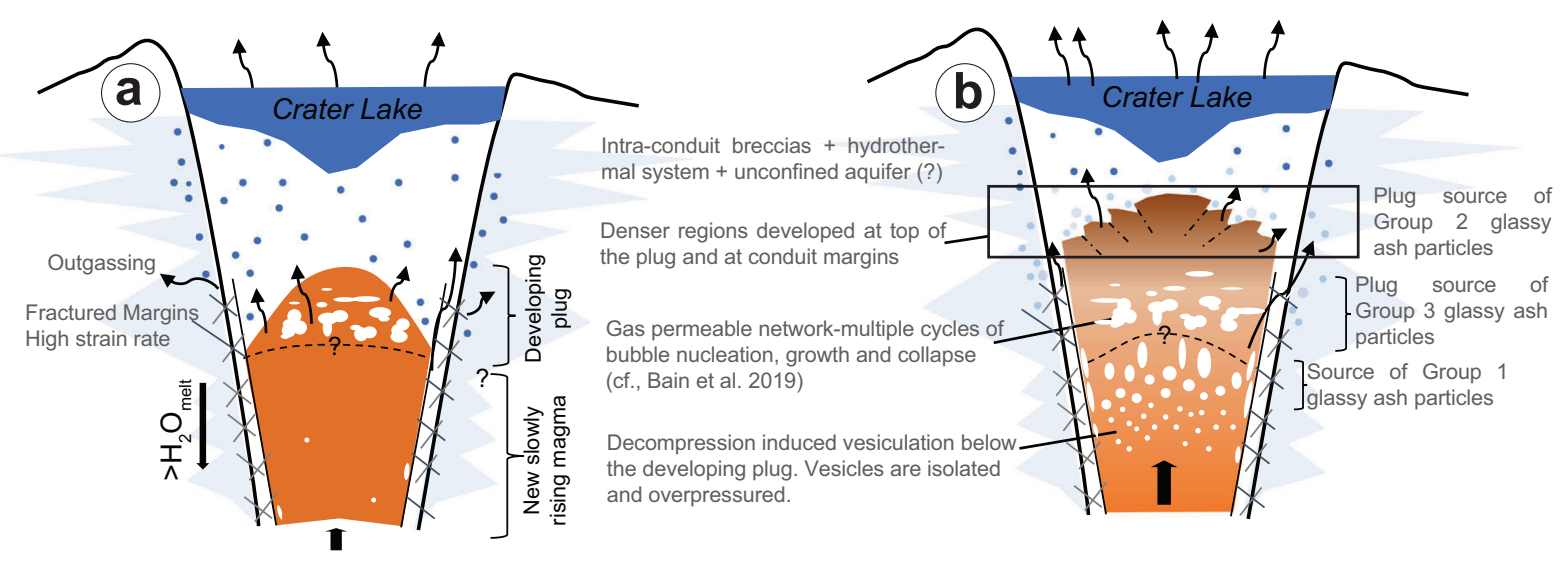

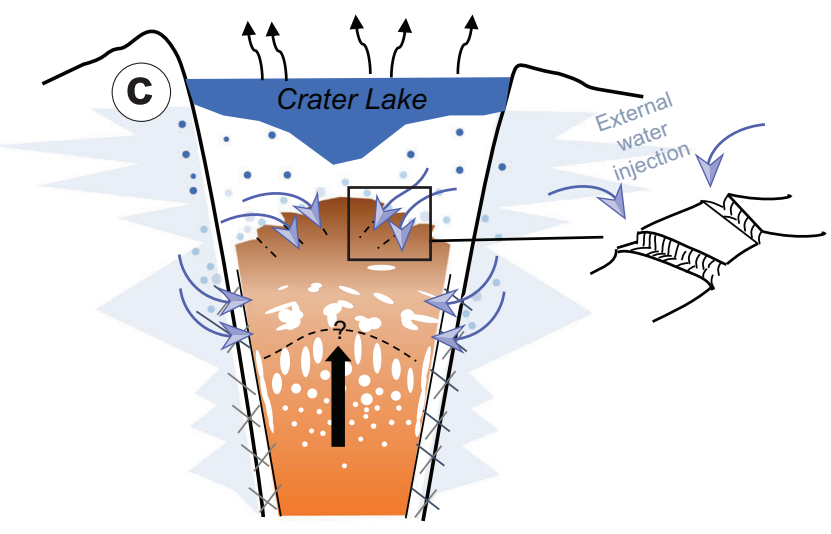

Fig. 8 Schematic model (not to scale) of Azufral silicic plug fragmentation. (a) Shallow conduit incipient plug develops (modifying Bain et al. 2019) between two eruptions. Between the dense cap and the vesiculating magma, a transitional zone develops as a gas-permeable network. At the margins, shearing and degassing occur. $\mathbf{b}$ Each zone of the differentially degassed magma/plug represents a source for the future

of vesicle nucleation, collapse and densification (Bain et al. 2019).

The abundance of juvenile glassy particles indicates that magma was involved in the successive explosions producing the dilute PDCs. The overall high microcrysts content in most samples reflects the advanced stage of degassing-induced crystallization of the rising magma before fragmentation (Sparks 1997). Also, the co-existing variable morphologies and microtextures of juvenile particles, at nearly constant chemical composition, in the same stratigraphic level, confirm that the physical state of the magma at the time of fragmentation was largely heterogeneous (Zhang 1999; Cashman and Blundy 2000). A shear thinning rheology (Lavallée et al. 2012) would mostly induce lateral textural variations in the shallow conduit due to shear at the conduit walls (Wallace et al. 2019), whereas a gas segregation mechanism (Michaut et al. 2013) could produce vertical variations.

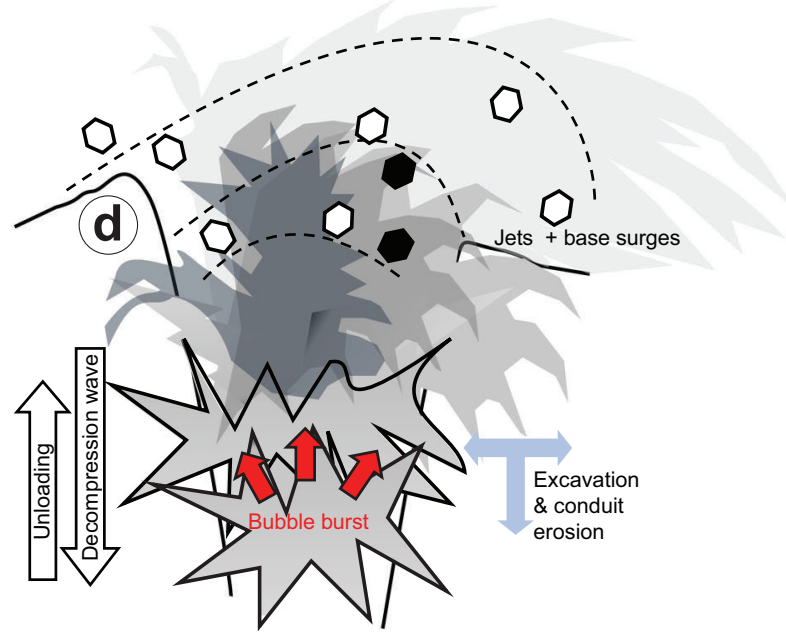

pyroclasts. $\mathbf{c}$ The capping and conduit lining zones crack while shearing upon rising. The newly developed cracks allow water injection from the lake or unconfined aquifer(s) driving $\mathbf{d}$ fragmentation and fracture propagation + decompression wave and conduit erosion. The original componentry is modified by segregation effects upon dilute PDC interaction with the crater rim

\section{Plug and magma fragmentation}

The combination of thinly bedded and cross-laminated sedimentary structures, the high accessory lithic/juvenile ratio and the fine-grained nature of juvenile components suggests an important role of explosive magma-water interaction at Azufral. A simultaneous magmatic and phreatomagmatic fragmentation mechanism explains the pulsatory fine fragmentation of the incipient plug (e.g. Cioni et al. 1992; Liu et al. 2015, 2017) in our study case.

Each glassy juvenile ash type can be linked to a specific conduit region, following the density "stratified" models of Wright et al. (2007), Giachetti et al. (2010) and Bain et al. (2019). On the one hand, glass particles showing low roughness (the platy and blocky particles of group 2; Figs. 5 and 6; Online Resource 3.2) likely derive from brittle fragmentation of capping and/or lateral dense and degassed portions (Fig. 8b). Some of these blocky-shaped 
particles are microcryst-bearing and, together with the platy-shaped particles, reflect brittle plug response to decompression. However, most of the equant/blocky particles are completely glassy and likely correspond to active particles of phreatomagmatic interactions (van Otterloo et al. 2015; Nurfiani and de Maisonneuve 2018). Indeed, the presence of stepped surfaces and quench cracks on the margins of some blocky grains confirms that these magma regions were the most affected by magma-water interaction (Büttner et al. 2002; van Otterloo et al. 2015).

On the other hand, comparable contents of high roughness glass particles with mostly isolated subspherical to ellipsoidal inner vesicles (group 1; Figs. 5 and 6; Online Resource 3.1) indicate that a portion of magma/plug was moderately vesiculated before fragmentation (Fig. 8b). Thus, magma volatiles also played a role in fragmentation and these particles might derive from rapid decompression of more vesicular (but still not very highly vesicular) magma (e.g. Sheridan and Wohletz 1983; Dellino and La Volpe 1996a; Nurfiani and de Maisonneuve 2018). The external surface of these particles suggests that they derive from melt portions separating large tube-like vesicles (Wright et al. 2009), perhaps from the sides of the conduit at depth.

Most of the fragmented juvenile material likely derived from a transition zone between dense and vesicular regions, explaining the predominant group 3 particles of intermediate roughness (Figs. 5, 6 and 7c). These particles likely derived from a variably degassed plug portion subjected to vesicle collapse evolving into highly interconnected paths (Fig. 8b; Online Resource 3.3).

The first step of molten-fuel coolant interaction (MFCI) in mafic systems is hydrodynamic mingling of magma and water (Heiken and Wohletz 1985; Zimanowski et al. 1998, 2015). This is unlikely for felsic systems due to strong viscosity contrasts. However, Büttner et al. (2006) and Austin-Erickson et al. (2008) demonstrated that hydraulic forcing of external water into cracks along the margins of a rising high-silica plug may create the required interface to induce phreatomagmatic explosions. In Azufral, the capping and conduit lining dense regions, and the permeable zones of the incipient plug, likely cracked (Tuffen et al. 2003, 2008; Forte and Castro 2019). The newly formed cracks could allow water injection and provide the contact surface required for effective phreatomagmatic interaction (Starostin et al. 2005) (Fig. 8c). This interaction favours the fine fragmentation of the plug (Fig. 8d) while enhancing ongoing magmatic processes, such as permeability variation and over-pressurization (Sparks 1997; Mueller et al. 2005) or fracture propagation (Lavallée et al. 2013).

The increasing lithic content observed with stratigraphic position, when comparing similar type-beds inside the crater, suggests increasing vent and/or conduit erosion over time (Barberi et al. 1989). This is accompanied by an increase in blocky and platy particles in samples $2 \mathrm{~B}-1 \mathrm{c}$ and $3 \mathrm{~A}-4 \mathrm{c}$ relative to underlying samples, in agreement with increasing magma-water interaction over time. In addition, the abundance of mafic crystals + Fe-Ti oxides within the uppermost (3A-4c) intra-crater bed and all extra-crater beds could reflect (a) decreasing magma temperature over time (Gardner and Denis 2004) and/or (b) lateral vent migration (Valentine et al. 2015). In addition, in the extra-crater beds (c) deposition of a larger number but smaller crystals as a result of breakage of larger ones during transport seems also to contribute to the relative abundance of mafics and Fe-Ti oxides (Online Resource 1.1).

\section{Particle transport}

A total grain-size distribution was not performed in this study. However, the analysed size ranges show interesting patterns that allow making some assumptions. The variations of bulk componentry (Fig. 7, Online Resource 1.1) shed light on dilute PDC transport processes, the effects of secondary fragmentation (e.g. Wohletz 1998; Manga et al. 2011; Dufek et al. 2012), elutriation (Freundt and Schmincke 1992; Horwell et al. 2001) and interaction with the topography (Sulpizio and Dellino 2008; Andrews and Manga 2012). For instance, the common high crystal content in the b-type beds inside the crater and low crystal content in all c-type beds (Fig. 7a) suggest that even at the fine-grained scale, physical fractionation processes can be seen. Heavy crystal enrichment occurs in the saltation and traction zones, while light and fragile accessory lithics and glassy juvenile particles are preferentially concentrated in the uppermost suspension-dominated turbulent zones.

The lateral changes from a lithic-rich succession inside the crater to pumice-rich exposures outside the crater (in terms of componentry of the whole deposit, not just the ash; see Castilla et al. 2018) is interpreted to result from the interaction of PDCs with the crater rim, which acts as a topographic barrier. Despite the impracticability of a detailed lateral correlation of individual beds and bed-sets, the general fine-very fine to extremely fine ash componentry variations are in agreement with the theoretical background exposed by Sulpizio and Dellino (2008) and Andrews and Manga (2012). In fact, the high concentration of crystals in all intra-crater bed types (except for the uppermost 3A-4c bed) indicates that these dense components are preferentially blocked by the topography or passively concentrated inside the crater. In contrast, accessory lithic and juvenile glass particles are able to overpass the topographic barrier.

\section{Conclusions}

By combining automated SEM/EDX single-particle analysis and $\mu \mathrm{X}-\mathrm{CT}$, fast and robust chemical and morpho-textural 
classification of fine to extremely fine ash particles is obtained. By studying these particles in a stratigraphic and sedimentary context we found, in the latest dilute PDC succession of Azufral, a natural example of simultaneous magmatic and phreatomagmatic fragmentation mechanisms. These mechanisms fragmented a silicic plug to produce thinly bedded deposits characterized by very fine to extremely fine (250-32 $\mu \mathrm{m})$ grain sizes. Variations in the relative contribution of each fragmentation mechanism might dictate fluctuations in the resulting particle/gas ratio of the pyroclastic mixture, subsequently transported/deposited in successive dilute PDCs. Physical fractionation processes related to primary and secondary fragmentation, elutriation and interaction with topography were identified, even in the fine to extremely fine ash. Our model implies a research challenge where we need to detect the timescales for plug density-stratification, plug shearing and cracking and the injection of external water, leading to fine fragmentation and multiple violent explosions through crater lakes.

Supplementary Information The online version contains supplementary material available at https://doi.org/10.1007/s00445-020-01418-z.

Acknowledgements Silvia Castillo, Hector Cepeda, Sergio Sarmiento and Santiago Villamil helped during fieldwork and sieving. Esteban Gaitán designed the protocol for 3D image processing. Dragon Fly staff produced the renders of segmented juvenile particles. Minerlab Ltda. (Bogotá), Ivette Cucubuná (Universidad de Los Andes) and Dettmar dissection Technology GmbH \& Co. KG (Germany) prepared thin sections. Dimitri Rouwet (INGV-Bologna, Italy) and Roberto Torres (OVSP-SGC, Pasto, Colombia) contributed with insightful discussions. Finally, we acknowledge the extensive constructive contributions from Dr. Daniela Mele (Universitá degli Studi di Bari Aldo Moro, Italy), Dr. Adrian Hornby (LMU, Germany) and the Bulletin of Volcanology Associate Editor Dr. Pierre-Simon Ross. Dr. Andrew Harris (Executive Editor of the same journal) carried out the final edits.

Funding This project was funded by (i) the Universidad de Los Andes through the FAPA grant allocated to N. Pardo; (ii) Banco de la República Project 4308 (Bogotá), through the agreement 201905 between "Fundación para la promoción de la investigación y la tecnología" and Universidad de Los Andes; and (iii) Particle Vision (Switzerland).

\section{References}

Albiridov MA, Dingwell DB (2000) Three fragmentation mechanisms for highly viscous magma under rapid decompression. J Volcanol Geotherm Res 100:413-421

Andrews BJ, Manga M (2012) Experimental study of turbulence, sedimentation, and coignimbrite mass partitioning in dilute pyroclastic density currents. J Volcanol Geotherm Res 225-226:30-44

Austin-Erickson A, Büttner R, Dellino P, Ort MH, Zimanowski B (2008) Phreatomagmatic explosions of rhyolitic magma: experimental and field evidence. J Geophys Res Solid Earth 113:B11201. https://doi. org/10.1029/2008JB005731

Bain AA, Calder ES, Cortés JA, Cortés GP, Loughlin SC (2019) Textural and geochemical constraints on andesitic plug emplacement prior to the 2004-2010 vulcanian explosions at Galeras volcano, Colombia. Bull Volcanol 81:article 1

Barberi F, Cioni R, Rosi M, Santacroce R, Sbrana A, Vecci R (1989) Magmatic and phreatomagmatic phases in explosive eruptions of Vesuvius as deduced by grain-size and component analysis of the pyroclastic deposits. J Volcanol Geotherm Res 38:287-307

Belousov A, Belousova M (2001) Eruptive process, effects and deposits of the 1996 and the ancient basaltic phreatomagmatic eruptions in Karkymskoye lake, Kamchatka, Russia. In: White JDL, Riggs NR (eds) Volcaniclastic sedimentation in lacustrine settings. Blackwell Sciences, Oxford, pp 35-60

Büttner R, Dellino P, Zimanowski B (1999) Identifying magma-water interaction from surface feature of ash particles. Lett Nat 401:688690

Büttner R, Dellino P, La Volpe L, Lorenz V, Zimanowski B (2002) Thermohydraulic explosions in phreatomagmatic eruptions as evidenced by the comparison between pyroclasts and products from Molten Fuel Coolant Interaction experiments. J Geophys Res Solid Earth 107:2277

Büttner R, Dellino P, Raue H, Sonder I, Zimanowski B (2006) Stressinduced brittle fragmentation of magmatic melts: Theory and experiments. J Geophys Res 111:B08204. https://doi.org/10.1029/ 2005JB003958

Calvache ML, Cortés GP, Torres MP, Monsalve ML (2003) Geología y estratigrafia del Volcán Azufral, Colombia, 52p., INGEOMINAS (Ed. Internal Report), Bogotá, Colombia: https://miig.sgc.gov.co/ Paginas/resultados.aspx?k=Calvache, $\% 202003, \% 20 \mathrm{Geolog} \% \mathrm{C} 3 \%$ ADa $\% 20$ y $\% 20$ estratigrafia $\% 20$ de $1 \% 20$ Volc $\%$ C3\% A $1 \mathrm{n} \%$ 20 Azufral

Carvajal D, Alfaro C, Molano-Mendoza JC, Romero D, Mojica J (2008) Contribution to the geothermal model of azufral volcano from identification of zones hydrothermal alteration. Geol Colomb 33:99-108 http://www.ciencias.unal.edu.co/unciencias/data-file/geociencias/ revistageologia/gcolombiana33/8-Carvajal.pdf

Cashman K, Blundy J (2000) Degassing and crystallization of ascending andesite and dacite. Philos Trans R Soc Lond A 358:1487-1513

Cashman KV, Sheu B (2015) Magmatic fragmentation. Chapter 25. In: Sirgudsson $\mathrm{H}$ et al (eds) The encyclopaedia of volcanoes, 2 nd edn. Academic, Cambridge, pp 459-471

Castilla SC, Pardo N, Larrea P, Zuluaga CA, Sarmiento S, Noguera D, Sarmiento GA (2018) Pre-eruptive conditions and pyroclastic emplacement of the last known Vulcanian eruption of Azufral Volcano, SW Colombia. J S Am Earth Sci 91:372-386. https://doi.org/10. 1016/j.jsames.2018.08.007

Cepeda H, Acevedo A, Lesmes L (1987) Características Químicas y Petrográficas de los Volcanes Azufral, Cumbal y Chiles-Cerro Negro, Colombia. S.A. Instituto Nacional de Investigaciones Geológico Mineras, Medellín Internal Report

Cioni R, D’Oriano C, Bertagnini A (2008) Fingerprinting ash deposits by their physical and textural features. J Volcanol Geotherm Res 177: 277-287

Cioni R, Sbrana A, Vecci R (1992) Morphologic features of juvenile pyroclasts from magmatic and phreatomagmatic deposits of Vesuvius. J Volcanol Geotherm Res 51:61-78

Cook E (1965) Stratigraphy of Tertiary volcanic rocks in eastern Nevada. Nev Bur Mines Rpt 11:66 p

Core Team (2013) R: A language and environment for statistical computing. R Foundation for Statistical Computing, Vienna. http:// www.R-project.org/

Dellino P, La Volpe L (1996a) Image processing analysis in reconstructing fragmentation and transportation mechanisms of pyroclastic deposits. The case of Monte Pilato-Rocche Rosse 
eruptions, Lipari (Aeolian Islands, Italy). J Volcanol Geotherm Res 71:13-29

Dellino P, La Volpe L (1996b) Cluster analysis on ash particles morphology features to discriminate fragmentation dynamics in explosive eruptions. Acta Vulcanol 8:31-39

Dellino P, Liotino G (2002) The fractal and multifractal dimension of volcanic ash particles contour: a test study on the utility and volcanological relevance. J Volcanol Geotherm Res 113:1-18

Dingwell DB (1998) Volcanic dilemma: flow or blow? Science 273: 1054-1155

Droux A, Delaloye M (1996) Petrography and geochemistry of PlioQuaternary calc-alkaline volcanoes of Southwestern Colombia. J S Am Earth Sci 9:27-41

Dufek J, Manga M, Patel A (2012) Granular disruption during explosive volcanic eruptions. Nat Geosci Lett 5:561-564

Dürig T, Mele D, Dellino P, Zimanowski B (2012) Comparative analyses of glass fragments from brittle fracture experiments and volcanic ash particles. Bull Volcanol 74:691-704

Dürig T, Bowman MH, White JDL, Murch A, Mele D, Verolino A, Dellino P (2018) Particle-shape analyser Partisan - an open source tool for multi-standard two-dimentional particle morphometry analysis. Ann Geophys 61:VO671. https://doi.org/10.4401/ag-7865

Ersoy O (2010) Surface area and volume measurements of volcanic ash particles by SEM stereoscopic imaging. J Volcanol Geotherm Res 190:290-296

Ersoy O, Chinga G, Aydar E, Gourgaud A, Cubukcu HE, Ulusoy I (2006) Texture discrimination of volcanic ashes from different fragmentation mechanisms: a case study, Mount Nemrut stratovolcano, eastern Turkey. Comput Geosci 32:936-946

Ersoy O, Gourgaud A, Aydar E, Chinga G, Thouret JC (2007) Quantitative SEM analysis of volcanic ash surfaces: application to the 1982-83 Galunggung eruption (Indonesia). Geol Soc Am Bull 119:743-752

Ersoy O, Aydar E, Gourgaud A, Bayhan H (2008) Quantitative analysis on volcanic ash surfaces: application of extended depth-of-field (focus) algorithm for light and scanning electron microscopy and 3D reconstruction. Micron 39:128-136

Ersoy O, Şen E, Aydar E, Tatar I, Çelik HH (2010) Surface area and volume measurements of volcanic ash particles using microcomputed tomography (micro-CT): a comparison with scanning electron microscope (SEM) stereoscopic imaging and geometric considerations. J Volcanol Geotherm Res 196:281-286

Fontaine E, Stix J (1993) Evolution pétrologique et géochimique du complexe de dômes du volcan Azufral (Colombie, Amérique du Sud). C R Acad Bulg Sci. Série 2, Mécanique, Physique, Chimie, Sciences de l'Univers, Sciences de la Terre 317:1501-1508

Forte P, Castro JM (2019) $\mathrm{H}_{2} \mathrm{O}$-content and temperature limit the explosive potential or rhyolite magma during Plinian eruptions. Earth Planet Sci Lett 506:157-167

Freundt BA, Schmincke HU (1992) Abrasion in pyroclastic flows. Geol Rundsch 81:383-389

Gardner JE, Denis MH (2004) Heterogeneous bubble nucleation on Fe-Ti oxide crystals in high-silica rhyolitic melts. Geochem Cosmochim Acta 68:3587-3597

Giachetti T, Druitt T, Burgisser A, Arbaret L, Galven C (2010) Bubble nucleation, growth and coalescence during the 1997 Vulcanian explosions of Soufrière Hills Volcano, Montserrat. J Volcanol Geotherm Res 193:215-231

Heiken G, Wohletz K (1985) Volcanic ash. University of California Press, Berkeley

Horwell CJ, Braña LP, Sparks RSJ, Murphy MD, Hards VLA (2001) Geochemical investigation of fragmentation and physical fractionation in pyroclastic flows from the Soufrière Hills volcano, Montserrat. J Volcanol Geotherm Res 109:247-262

Houghton BF, Wilson CJN (1989) Vesicularity index for pyroclastic deposits. Bull Volcanol 51:451-462
Houghton B, White JDL, Van Eaton AR (2015) Phreatomagmatic and related eruption styles. In: Sirgudsson H et al (eds) The encyclopaedia of volcanoes, 1st edn. Academic, London, pp 431-445

Inguaggiato C, Burbano V, Rowet D, Garzón G (2017) Geochemical processes assessed by Rare Earth Elements fractionation at "Laguna Verde" acidic-sulphate crater lake (Azufral volcano, Colombia). Appl Geochem 79:65-74

Kilgour G, Manville V, Della Pasqua F, Graettinger A, Hodgson KA, Jolly GE (2010) The 25 September 2007 eruption of Mount Ruapehu, New Zealand: directed ballistics, surtseyan jets, and iceslurry lahars. J Volcanol Geotherm Res 191:1-14

Kilgour G, Gates S, Kennedy B, Farquhar A, McSporran A, Asher C (2019) Phreatic eruption dynamics derived from deposit analysis: a case study from a small, phreatic eruption from Whakāri/White Island, New Zealand. Earth Planets Space 71:36

Kokelaar BP (1983) The mechanism of Surtseyan volcanism. J Geol Soc Lond 140:939-994

Krumbein WC (1934) Size frequency distributions of sediments. J Sediment Petrol 4:65-77

Laskin A, Cowin JO (2001) Automated single-particle SEM/EDX analysis of submicrometer particles down to $0.1 \mu \mathrm{m}$. Anal Chem 73: 1023-1029

Lavallée Y, Benson PM, Heap MJ, Flaws A, Hess KU, Dingwell DB (2012) Volcanic conduit failure as a trigger to magma fragmentation. Bull Volcanol 74:11-13

Lavallée Y, Benson PM, Heap MJ, Hess KU, Flaws A, Schillinger B, Meredith PG, Dingwell DB (2013) Reconstructing magma failure and degassing network of dome building eruptions. Geology 41: $515-518$

Liu EJ, Cashman KV, Rust AC (2015) Optimising shape analysis to quantify volcanic ash morphology. GeoResJ 8:14-30

Liu EJ, Cashman KV, Rust AC, Höskuldsson A (2017) Contrasting mechanisms of magma fragmentation during coeval magmatic and hydromagmatic activity: the Hverfjall Fires fissure eruption, Iceland. Bull Volcanol 79:article 68

Manga M, Patel A, Dufek J (2011) Rounding of pumice clasts during transport: field measurements and laboratory studies. Bull Volcanol 73:321-333

Mastin LG, Witter JB (2000) The hazards of eruptions through lakes and seawater. J Volcanol Geotherm Res 97:195-214

Meier MF, Mildenberger T, Locher R, Rausch J, Zünd T, Neururer C, Ruckstuhl A, Grobéty B (2018) A model based two-stage classifier for airborne particles analyzed with Computer Controlled Scanning Electron Microscopy. J Aerosol Sci 123:1-6

Mele D, Dellino P, Sulpizio R, Braia G (2011) A systematic investigation on the aerodynamics of ash particles. J Volcanol Geotherm Res 203: $1-11$

Mele D, Dioguardi F, Dellino P (2018) A study on the influence of internal structures on the shape of pyroclastic particles by X-ray microtomography investigations. Ann Geophys 61:VO670. https:// doi.org/10.4401/ag-7868

Melnik O, Sparks SJ (2002) Dynamics of magma ascent and lava extrusion at Soufriére Hills Volcano, Montserrat. Geol Soc Lond Mem 21:153-171. https://doi.org/10.1144/GSL.MEM.2002.021.01.07

Michaut C, Ricard Y, Bercovici D, Sparks RSJ (2013) Eruption cyclicity at silicic volcanoes potentially caused by magmatic gas waves. Nat Geosci Lett 6:856-860

Montanaro C, Scheu B, Gudmundsson MT, Vogfjörd K, Reunolds HI, Dürig T, Strehlow K, Rott S, Reuschelè T, Dingwell DB (2016) Multidisciplinary constraints of hydrothermal explosions based on the 2013 Gengissig lake events, Kverkfjöll volcano, Iceland. Earth Planet Sci Lett 434:308-319

Moore JG (1967) Base surge in recent volcanic eruptions. Bull Volcanol 30:337-363 
Mueller S, Melnik O, Spieler O, Scheu B, Dingwell DB (2005) Permeability and degassing of dome lavas undergoing rapid decompression: an experimental determination. Bull Volcanol 67:526-538

Németh K, Cronin SJ, Charley D, Harrison M, Garae E (2006) Exploding lakes in Vanuatu-Surtseyan-style eruptions witnessed on Ambae Island. Episodes 29:87-92

Nurfiani D, de Maisonneuve B (2018) Furthering the investigation of eruption styles through quantitative shape analyses of volcanic ash particles. J Volcanol Geotherm Res 354:102-114

Pardo N, Cronin SJ, Németh K, Brenna M, Schipper CI, Breard E, White JDL, Procter J, Stewart B, Agustín-Flores J, Moebis A, Zernack A, Kereszturi G, Lube G, Auer A, Neall V, Wallace C (2014) Perils in distinguishing phreatic from phreatomagmatic ash: insights into the eruption mechanisms of the 6 August $2012 \mathrm{Mt}$. Tongariro eruption, New Zealand. J Volcanol Geotherm Res 286:397-414

Rausch J, Grobéty B, Vonlanthen P (2015) Eifel maars: Quantitative shape characterization of juvenile ash particles (Eifel Volcanic Field, Germany). J Volcanol Geotherm Res 291:86-100

Ringnér M (2008) What is principal component analysis? Nat Biotechnol 26:303-304

Rouwet D, Morrissey MM (2015) Mechanisms of Crater Lake breaching eruptions. In: Rowet D, Christenson B, Tassi F, Vandemeulebrouck $\mathrm{J}$ (eds) Advances in Volcanology-Volcanic Lakes. Springer-Verlag, Berlin, pp 73-92

Sarmiento SE (2017) Mecanismos de transporte y acumulación de los depósitos más recientes del volcán Azufral. BSc thesis, Department of Geosciences, National University of Colombia, Bogotá, Colombia

Schneider CA, Rasband WS, Eliceiri KW (2012) NIH Image to ImageJ: 25 years of image analysis. Nat Methods 9:671-675

Sheets KG, Jun B, Zhou Y, Winkler J et al (2011) Topical neuroprotectin D1 attenuates experimental CNV and induces activated microglia redistribution. Investig Ophthalmol Vis Sci 52:5470-5470

Sheridan MF, Wohletz KH (1983) Hydrovolcanism: basic considerations and review. J Volcanol Geotherm Res 17:1-29

Skyscan (2009) Structural parameters measured by SkyScan ${ }^{\text {TM }}$ CTanalyzer software, 36p. Belgium, https://www.microphotonics. com/wp-content/uploads/2016/01/CTAn_parameters.pdf

Sparks RSJ (1997) Causes and consequences of pressurisation in lava dome eruptions. Earth Planet Sci Lett 150:177-189

Starostin AB, Barmin AA, Melnik OE (2005) A transient model for explosive and phreatomagmatic eruptions. J Volcanol Geotherm Res 143:133-151

Sulpizio R, Dellino P (2008) Sedimentology, depositional mechanisms and pulsating behaviour of pyroclastic density currents. In: Martí J, Gottsman J (eds) Caldera volcanism: analysis, modelling and response. Developments in Volcanology, vol 10. Elsevier, Amsterdam, pp 57-96

Taddeucci J, Pompilio M, Scarlato P (2002) Monitoring the explosive activity of the July-August 2001 eruption of Mt. Etna (Italy) by ash characterization. Geophys Res Lett 29:1230. https://doi.org/10. 1029/2001GL014372

Taddeucci J, Scarlato P, Andronico D, Cristaldi A, Büttner R, ZImanowski B, Küppers U (2007) Advances in the study of volcanic ash. EOS 88:253-260

Tuffen H, Dingwell DB, Pinkerton H (2003) Repeated fracture and healing of silicic magma generate flow banding and earthquakes? Geology 31:1089-1092

Tuffen H, Smith R, Sammonds PR (2008) Evidence for seismogenic fracture of silicic magmas. Nature 453:511-514
Valentine GA, Graettinger AH, Macorps E, Ross PS, White JDL, Döhring E, Sonder I (2015) Experiments with vertically and laterally migrating subsurface explosions with applications to the geology of phreatomagmatic and hydrothermal explosion craters and diatremes. Bull Volcanol 77:article 15

Van Otterloo J, Cas RAF, Scutter CR (2015) The fracture behaviour of volcanic glass and relevance to quench fragmentation during deformation of hyaloclastite and phreatomagmatism. Earth Sci Rev 151: $79-116$

Vazquez JA, Ort MH (2006) Facies variation of eruption units produced by the passage of single pyroclastic surge currents, Hopi Buttes volcanic field, USA. J Volcanol Geotherm Res 154:222-236

Villamil SE (2018) Mecanismos de fragmentación, transporte y acumulación de la unidad La Cortadera, del Volcán Azufral (Nariño). BSc thesis, Departamento de Geociencias, Universidad de Los Andes, Bogotá, Colombia

Vonlanthen P, Rausch J, Ketcham RA, Putlitz B, Baumgartner LP, Grobéty B (2015) High-resolution 3D analyses of the shape and internal constituents of small volcanic ash particles: the contribution of SEM micro-computed tomography (SEMmicro-CT). J Volcanol Geotherm Res 293:1-12

Wadsworth FB, Witcher T, Vossen CEJ, Hess K-U, Unwin HE, Scheu B, Castro JM, Dingwell DB (2018) Combined effusive-explosive silicic volcanism straddles the multiphase viscous-to-brittle transition. Nat Commun 9:4696. https://doi.org/10.1038/s41467-018-07187-w

Wallace PA, Kendrick JE, Miwa T et al (2019) Petrological architecture of magmatic shear zone: a multidisciplinary investigation of strain localisation during magma ascent at Unzen Volcano, Japan. J Petrol 60:791-826

White JDL, Houghton BF (2006) Primary volcaniclastic rocks. Geology 34:677-680

Williams M, Bursik MI, Cortes GP, Garcia AM (2017) Correlation of eruptive products, Volcán Azufral, Colombia: Implications for rapid emplacement of domes and pyroclastic flow units. J Volcanol Geotherm Res 341:21-32

Wohletz KH (1983) Mechanisms of hydrovolcanic pyroclast formation: grain-size, scanning electron microscopy, and experimental studies. In: Sheridan MF, Barberi F (eds) Explosive Volcanism, J Volcanol Geotherm Res, vol 17, pp 31-63

Wohletz KH (1998) Pyroclastic surges and compressible two-phase flow. In: Freundt A, Rosi M (eds) From magma to tephra: modelling physical processes of explosive volcanic eruptions. North Holland, Elsevier, pp 247-312

Wright HMN, Cashman KV, Rosi M, Cioni R (2007) Breadcrust bombs as indicators of vulcanian eruption dynamics at Guagua Pichincha volcano, Ecuador. Bull Volcanol 69:281-300

Wright HMN, Cashman KV, Gottesfeld EH, Roberts JJ (2009) Pore structure of volcanic clasts: measurements of permeability and electrical conductivity. Earth Planet Sci Lett 280:93-104

Zhang Y (1999) A criterion for the fragmentation of bubbly magma based on brittle failure theory. Nature 402:648-650

Zimanowski B, Fröhlich G, Lorenz V (1991) Quantitative experiments on phreatomagmatic explosions. J Volcanol Geotherm Res 48:341-358

Zimanowski B, Büttner R, Lorenz V (1998) Premixing of magma and water in MFCI experiments. Bull Volcanol 58:491-495

Zimanowski B, Büttner R, Dellino P, White DL, Wohletz KH (2015) Magma-water interaction and phreatomagmatic fragmentation. In: Sigurdsson H (ed) The Encyclopaedia of Volcanoes, 2nd. edn. Elsevier, Amsterdam, pp 473-484 